\title{
3D deformation in strike-slip systems: Analogue modelling and numerical restoration
}

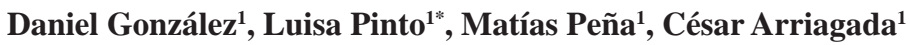

1 Departamento de Geología, Universidad de Chile, Casilla 13518, Correo 21, Santiago, Chile.
dagonzag@gmail.com; lpinto@ing.uchile.cl; geodeckard@gmail.com; cearriag@cec.uchile.cl
*Corresponding author: lpinto@ing.uchile.cl

\begin{abstract}
Regional and local strike-slip systems in Chile are complex and pose interesting questions, such as the interaction between strike-slip and reverse faults, how they evolve, and the relationship between shortening, rotation and uplift. Within this context, we developed a new analytical method based on analogue and numerical modelling applied to 3D, pure and transtensional-transpressional strike-slip systems. Analogue modelling results indicate that in restraining stepovers of strike-slip fault systems, where antiformal pop-up structures are usually formed, pre-existent basement structures with a high angle to the main strike-slip fault will generate a higher rotation of blocks. However, when these structures are oriented at a high angle with respect to the main stress convergence vector, the rotation will be less and therefore a higher tendency to uplift will be produced. These results were applied to NW- and SE-striking basement faults oblique to N-S mega-thrust faults in central Chile $\left(32^{\circ}-35^{\circ} \mathrm{S}\right)$, for which we propose a simultaneous development based on the analogue model results. Moreover, we propose that strike-slip movement occurred on thrust faults in central Chile. Furthermore, we performed a numerical restoration of an analogue experiment which modeled a pure strike-slip system, and concluded that the restoration is very sensitive to shortening data as well as to rotational data. These results are extremely important for future numerical and regional analysis of strike-slip systems.
\end{abstract}

Keywords: 3D, Analogue modelling, Numerical restoration, Strike-slip system, Transpression-transtension.

RESUMEN. Deformación 3D en sistemas de rumbo: modelación analógica y restauración numérica. Los sistemas de rumbo regionales y locales en Chile son complejos y plantean interesantes preguntas, tales como la interacción entre fallas de rumbo y fallas inversas, cómo evolucionan ellas, y la relación entre acortamiento, rotación y alzamiento. En este contexto, desarrollamos un nuevo método analítico basado en modelamiento analógico y numérico de sistemas de rumbo de cizalle puro y sistemas transpresionales-trantensionales en 3D. Los resultados del modelamiento analógico indican que en los 'restraining stepovers' de sistemas de rumbo, donde se forman normalmente anticlinales pop-up, estructuras de basamento preexistentes con un alto ángulo respecto a la falla de rumbo principal generarán una mayor rotación de bloques. Sin embargo, cuando estas estructuras están orientadas a altos ángulos con respecto al vector de esfuerzo principal, la rotación será menor y, por lo tanto, producirán una mayor tendencia al alzamiento. Estos resultados fueron aplicados a estructuras de rumbo NW y SE en el basamento oblicuas a megasistemas inversos norte-sur en Chile Central $\left(32^{\circ}-35^{\circ} \mathrm{S}\right)$, para las cuales propusimos un desarrollo contemporáneo. Además, basados en los resultados de nuestros modelos, proponemos que las megafallas inversas de Chile Central presentan un movimiento de rumbo. Asimismo, realizamos una restauración numérica de un experimento analógico que modelaba un sistema de rumbo de cizalle puro, y concluimos que la restauración es muy sensible a los datos de acortamiento, así como a los datos de rotación. Estos resultados son extremadamente importantes para futuros análisis numéricos y regionales de sistemas de rumbo. 


\section{Introduction}

The Chilean Andes provides a natural laboratory for investigating the nature of thick- and thin-skinned deformation along a convergent plate margin. Structures formed along this margin reflect subduction parameters such as plate velocity, intensity of the coupling, and the obliquity vector of the movement with respect to the plate boundary (Reutter et al., 1996). These structures have an architecture and kinematics that, at various scales, can provide important information on the evolution of deformation, the relationship between regional deformation and the local stress pattern, and relationships with the plate convergence parameters.

Because of the change in convergence velocity and obliquity angle from $10 \mathrm{~mm} / \mathrm{y}$ to $100 \mathrm{~mm} / \mathrm{y}$ and from $80^{\circ}$ to $40^{\circ}$, respectively, that occurred in the Chilean Andes during the Early Eocene (Pardo-Casas and Molnar, 1987), deformation at some latitudes has occurred along a series of strike-slip systems with a significant partitioned deformation along their strike (Pardo-Casas and Molnar, 1987; Scheuber et al., 1994). These strike-slip systems developed in several periods of geological time, i.e., the Early Cretaceous and the Oligocene (Scheuber et al., 1994), and their structures channeled hydrothermal fluids that formed large porphyry $\mathrm{Cu}$ systems. These systems are also associated to areas of seismic activity (e.g., Reutter et al., 1996; Scheuber and Giese, 1999; Amilibia et al., 2008).

There are three important mega-strike-slip systems in Chile, the Atacama Fault Zone, the Domeyko Fault Zone of northern Chile (Fig. 1a) and the Liquiñe-Ofqui Fault Zone of southern Chile (Fig. 1b) (e.g., Cembrano et al., 1996; Scheuber and Andriessen, 1990; Yáñez et al., 1994; Kuhn and Reuther, 1999). These large systems have stepovers along their strikes where sigmoidal antiformal pop-up structures or pull-apart basins are developed (e.g., Sylvester and Smith, 1987; Christie-Blick and Biddle, 1985) or strike-slip structures arranged as duplexes (Cembrano et al., 2005) and en-echelon shear patterns (Taylor et al., 1998) affecting the sedimentary cover and basement. In these systems, the development of oblique inversion has been recognized (Amilibia et al., 2008). It has also been determined that the transpressional systems are strongly associated with the emplacement of porphyry copper deposits (e.g., Amilibia et al., 2008; Reutter et al., 1996; Tomlinson and Blanco, 1997). While paleomagnetic studies carried out by Astudillo et al. (2008) in the Chuquicamata mine have shown the complex relationship existing between block tectonic rotations and strike-slip deformation zones. Besides a strong correlation between total displacement and internal fault structure have been documented by Cembrano et al. (2005) in the Atacama Fault System. All these studies on strike-slip systems have made it possible to constrain their kinematics, geometry and relative chronology. However, there are still some remaining questions on how these systems were formed and evolved. For example, the influence of basement discontinuities on deformation of the sedimentary cover is not well understood at these latitudes, because structural studies in these systems are scarce (Cembrano et al., 1992). On the other hand, a 'mega-domino' regional model for Atacama Fault Zone of northern Chile has been proposed by Grocott and Taylor (2002). This model considered a large amount of rotational data, but few shortening data. Recent studies (Martínez et al., 2009; Peña et al., 2009) refined this model using shortening data and the obtained results produced a more detailed regional model.

In this context, analogue modelling emerges as an important tool to identify the most influential parameters, and is also a way to see how these parameters are interrelated to generate different landforms in a laboratory-scale reproduction (e.g., Naylor et al., 1986; Mandl, 1988; Richard et al., 1989; Withjack et al., 1990; Vendeville, 1991; Lallemand et al., 1992; Malavieille et al., 1993; Schreurs, 1994; Yagupsky et al., 2008). In addition, the use of numerical restoration provides a powerful tool to quantify the exact amount of deformation (shortening and rotation of blocks) and better constrain its evolution (e.g., Rouby et al., 1993, 1996; Bourgeois et al., 1997; McClay and Bonora, 2001; Arriagada et al., 2008).

Several studies have recorded the presence of antiformal pop-up structures in plan view reproduced in sandbox models (McClay and Bonora, 2001) and have also developed methodologies to make palinspastic restorations for certain tectonic regimes (Rouby et al., 1993, 1996; Bourgeois et al., 1997; Arriagada et al., 2008). However, no study has yet been undertaken on the interrelationships of these strike-slip structures in this kind of model. Here we combined plan view geometries from analogue models with numerical restorations to analyze the development of these systems in transpressional and 

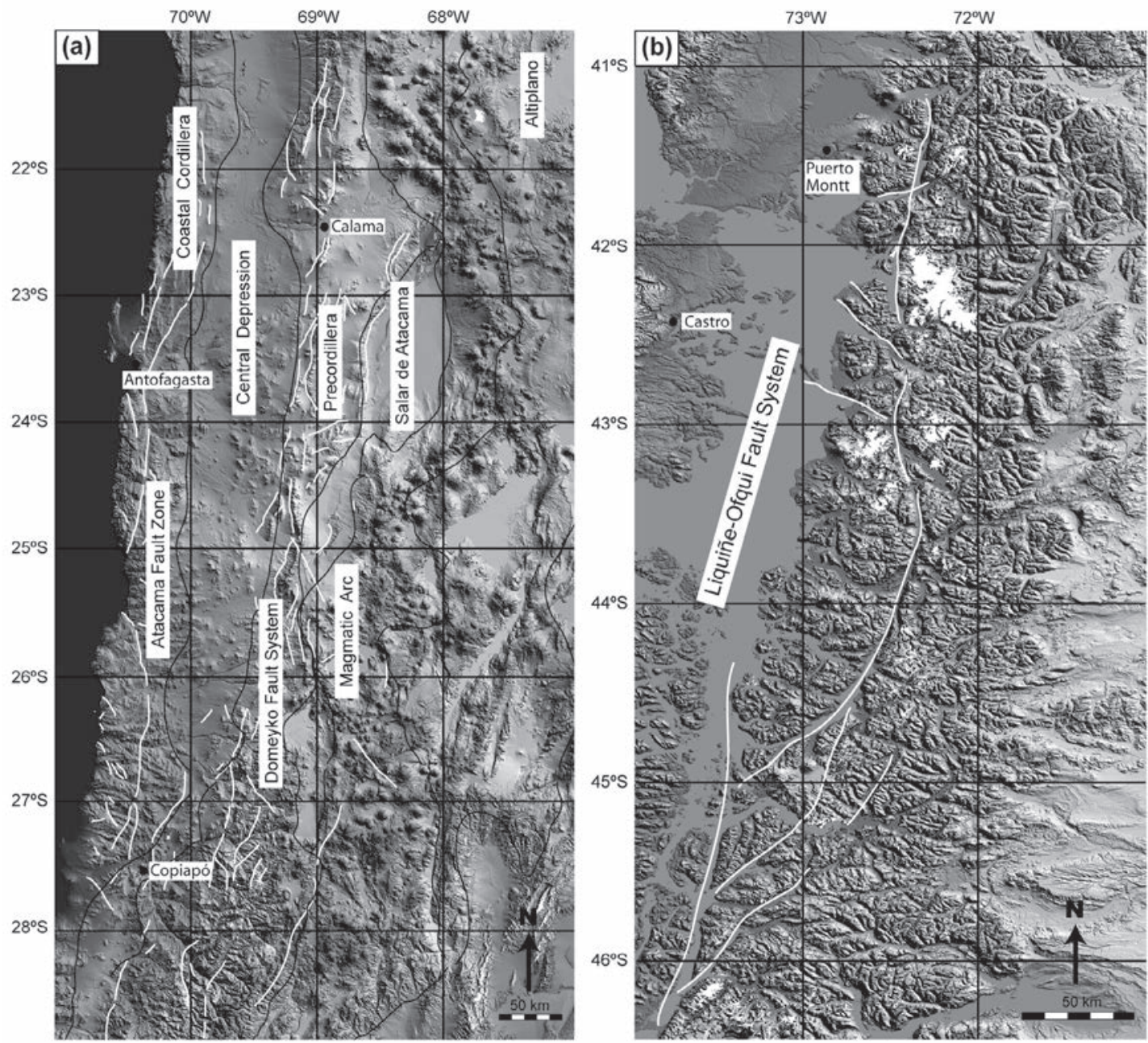

FIG. 1. Strike-slip structural systems in Chile: a. Represents the principal fault systems in the northern Chile, such as the Atacama Fault Zone and the Domeyko Fault System; b. Represents the southern Liquiñe-Ofqui Fault System. The white lines represent strike-slip faults systems and structural lineaments proposed in previous studies (Cembrano et al., 2000; Taylor et al., 2007; Amilibia et al., 2008; Arriagada et al., 2008; Charrier et al., 2009).

transtensional zones, under controlled stress vectors and in the presence of basement faults prior to deformation. We aimed to recognize the influence of the geometry of discontinuities in the basement and the direction of the stress tensor in order to establish the degree of confidence a numerical model would have, given a certain amount of structural data with respect to a controlled case from an analogue experiment. It is of interest to know how much of the deformation we can restore, knowing the prekinematic state, in order to apply the results to the strike-slip megasystems and thus gain a clearer understanding of their structural evolution.

\section{Analogue modelling}

\subsection{Methodology}

Analogue modelling methodology applied in this study corresponds to the classical configuration of restraining or releasing stepovers of strike-slip fault systems with the generation of antiformal pop-up structures and pull-apart basins, respectively. We chose the dextral movement in the strike-slip system. The design and deformation of strike-slip systems in this study are in agreement with the models presented by McClay and Bonora (2001) 
and Wu et al. (2009) (Fig. 2). A difference is that we considered two antithetic stepovers on the strike-slip system to compare the different structural geometries produced on the sedimentary cover associated with each stepover. The experiments were performed at fragile crust scale (upper crust), thus quartz sand was used with a mean grain diameter of less than $500 \mu \mathrm{m}$, which deforms according to the Navier-Coulomb criteria (Hosrfield, 1977; Schreurs, 1994; Richard et al., 1995; McClay and Dooley, 1995). This sand was placed in layers of alternating black and white colors to facilitate observations (Fig. 2c). The scale of this model was fixed to represent $1 \mathrm{~cm}=1 \mathrm{~km}$ following McClay (1990).

Experiments were performed using two different setups. The first setup for a pure strike-slip system consisted of a piston attached to a wall, on which a mobile plate, $0.3 \mathrm{~mm}$ thick, was attached on the narrow side (Fig. 2a). The sandbox measured $94 \mathrm{~cm}$ by $50 \mathrm{~cm}$. Its shape was determined by the direction of motion required for the first set of models (see below). The second setup for the transpressionaltranstensional system consisted of a piston attached to a wall, on which a mobile plate, $0.3 \mathrm{~mm}$ thick, was attached on the wider side, to generate oblique movement for the last two sets (Fig. 2b). The dimensions of the sandbox in this setup were 100 cm by $50 \mathrm{~cm}$.

The geometry of the metal plate included two antithetic stepovers to generate a velocity discontinuity (VD), which simulated discontinuities of the basement (Figs. 2a and 2b). This plate was moved parallel to another fixed plate, considering a $0^{\circ}$ convergence angle in the first set (Figs. 2a and $2 \mathrm{~d}$ ). In the other sets, with $30^{\circ}$ and $45^{\circ}$ convergence angle, the mobile plate was moved laterally using a rotational device added between the piston and the wall (Fig. 2b).

A previous study by Yagupsky et al. (2008) analyzed the influence of basement structures, but in a context of normal faults reactivated in a contractional environment, which are inverted only in certain specific conditions. McClay and Bonora (2001) and Wu et al. (2009) have also analyzed the influence of basal discontinuities, but in the first case they only studied the influence of stepovers in pure strike-slip systems and in the second case only pull-apart basins in pure and transtensional strike-slip systems. In this study we ensured the activity of basement faults and focused our experiments on the resulting geometries produced on the surface for pure and transpressionaltranstensional strike-slip systems. a)
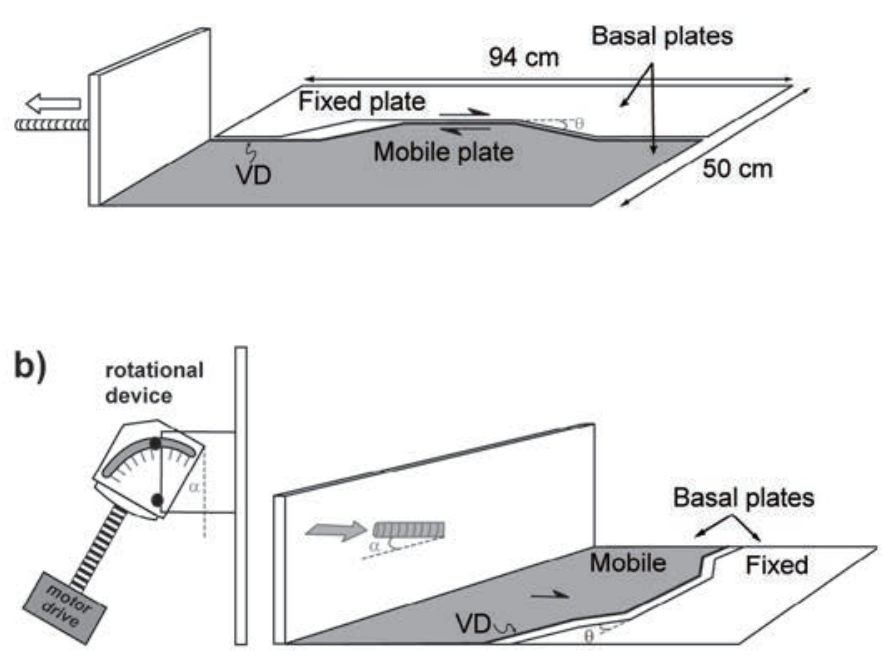

c)

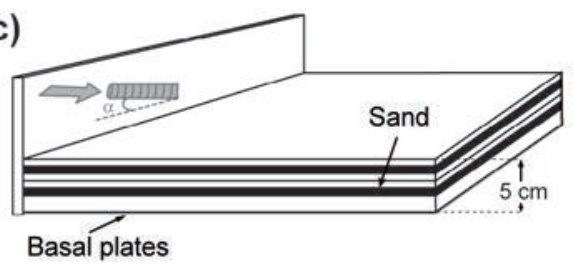

d)
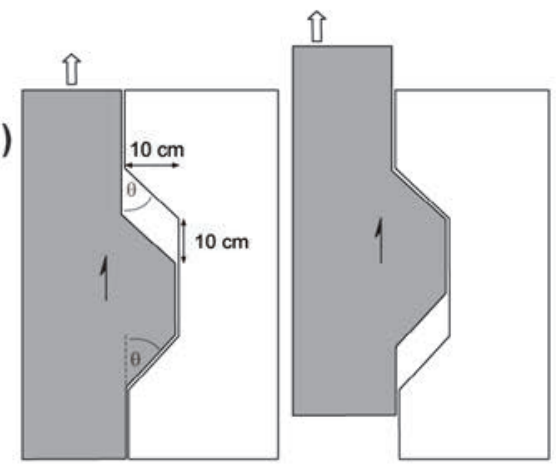

FIG. 2. a. Experimental device for the set with $0^{\circ}$ convergence angle. The stepover angle, ' $\theta$ ', is indicated; $\mathbf{b}$. Experimental device for the sets with $30^{\circ}$ and $45^{\circ}$ convergence angle ' $\alpha$ ', which is indicated behind the mobile wall. Rotational device is also shown; c. Geometry and dimensions of the standard sandbox; $\mathbf{d}$. Example of plate motion for the case of a $0^{\circ}$ convergence angle and stepover angle of $\theta\left(30^{\circ}, 45^{\circ}\right.$ or $60^{\circ}$ depending on the set $)$. 
The displacement was applied at a rate of $3 \mathrm{~cm} / \mathrm{h}$ for $3.3 \mathrm{~h}$ (200 $\mathrm{min})$, in the three sets with different angles between the wall and the piston $\left(0^{\circ}, 30^{\circ}\right.$ and $45^{\circ}$ ), reaching $10 \mathrm{~cm}$ of displacement (Figs. 3 and 4). Each set consisted of three further experiments with different angles of stepover discontinuity $\left(30^{\circ}\right.$, $45^{\circ}$ and $60^{\circ}$ ) to quantify the influence of both angles in the geometry and the evolution of deformation (Figs. 3 and 4).

Prior to deformation, a grid with circles inside each square was placed on top of the sandbox in order to visualize progressive movements and rotations (Fig. 3). The evolution of the deformation was recorded by photographs every 5 minutes. At the end of each experiment, cross-cuts with respect to the main strike-slip zone were made to analyze the final structures. We defined the main directional movement for every experiment as $\mathrm{N}-\mathrm{S}$ in order to describe the relative orientation of the structures. The cross-sections were made every $3 \mathrm{~cm}$ over the whole deformed zone. Representative cross-sections from the models are shown in Figs. 5 and 6.

The geometry and temporal characteristics of popups and pull-apart basins generated in all models are illustrated in Figs. 3, 4 and 5. Plan view images and cross-sections were used to calculate the width and depth of the structures, measured perpendicular to the curvature of the stepover and also parallel to the main track movement. For pop-ups, the conserved and rotated lines of the grid were used to estimate the final cumulative vertical axis rotation of their blocks. We determined an average rotation considering the rotation associated to each line within each block of the pop-up and then we established an average angle of rotation for each pop-up in the experiment. In addition, the timing of the main structures was studied to obtain information on the evolution of the deformation.

\subsection{Experimental Results}

As mentioned before, this study considered two main parameters: the convergence angle and the stepover angle. To analyze their influence on the deformation separately, one of the angles was set and the other was variable. This generated a matrix of nine experiments with the following combinations (Figs. 3 and 4): a first set of pure strike-slip system with $0^{\circ}$ convergence angle and $30^{\circ}, 45^{\circ}$ and $60^{\circ}$ stepover angles (Figs. 3a-c and $4 \mathrm{a}-\mathrm{c}$ ); a second set of transpressional-transtensional strike-slip system with $30^{\circ}$ convergence angle and $30^{\circ}, 45^{\circ}$ and $60^{\circ}$ stepovers (Figs. 3d-f and 4d-f); and a third set of transpressional-transtensional strike-slip system with $45^{\circ}$ convergence angle and $30^{\circ}, 45^{\circ}$ and $60^{\circ}$ stepover angles (Figs. 3g-i and 4g-i). The results for each set and comparisons among the different sets are presented in the following sections and summarized in Table 1.

\subsubsection{Set with $0^{\circ}$ convergence angle}

For this set of three experiments the first setup (Figs. 2a and 2d) was used, which allowed a pure strike-slip system with $0^{\circ}$ convergence angle fixed for the entire set (Figs. 3a-c and 4a-c). The following describes the overall results of the set and then the specific characteristics of each experiment.

Over the southern stepover of the sandbox a pull-apart basin was formed, while a pop-up system developed over the northern stepover (Figs. 3a-c and $4 a-c)$. The shape of the pull-apart basin was sigmoidal to rhomboidal, bounded by two NW oriented normal fault zones directly related to the discontinuities of the basement represented by the stepover in depth (Figs. 4a-c and 6a-c). The pop-up was limited by four fault zones with a reverse and dextral movement. It had a sigmoidal to rhomboidal geometry that became wider and shorter with higher stepover angles (Figs. $4 a-c$ and $5 a-c)$. This geometry was clearly shown by the fact that the fault zones bounding the $\mathrm{E}$ and $\mathrm{W}$, both the pop-up and the pull-apart basin, coincided with the projection on surface of the stepover angles in the basement. Moreover, in both cases a larger structure on the western edge (e.g., faults 2 and 9 in Fig. 4b) was generated compared to the eastern edge where a series of faults, reverse or normal, were generated (e.g., faults 3, 4, 8 and 13 in Fig. 4b), according to weather it corresponded to a pop-up or a pull-apart basin, respectively (Figs. 5a-c and 6a-c). This asymmetry of the deformation is an artifact of the experimental setup and is explained by the western location of the mobile plate, causing the deformation to be absorbed into a single structure on this edge, while on the east side it did so in several structures.

The development of this set of experiments usually began with the formation of the southern pull-apart basin followed by the formation of a bulge which later turned into the northern pop-up system. In the pop-up, the eastern structures were developed in normal sequence showing the deformation spread 
Angle of basement stepover

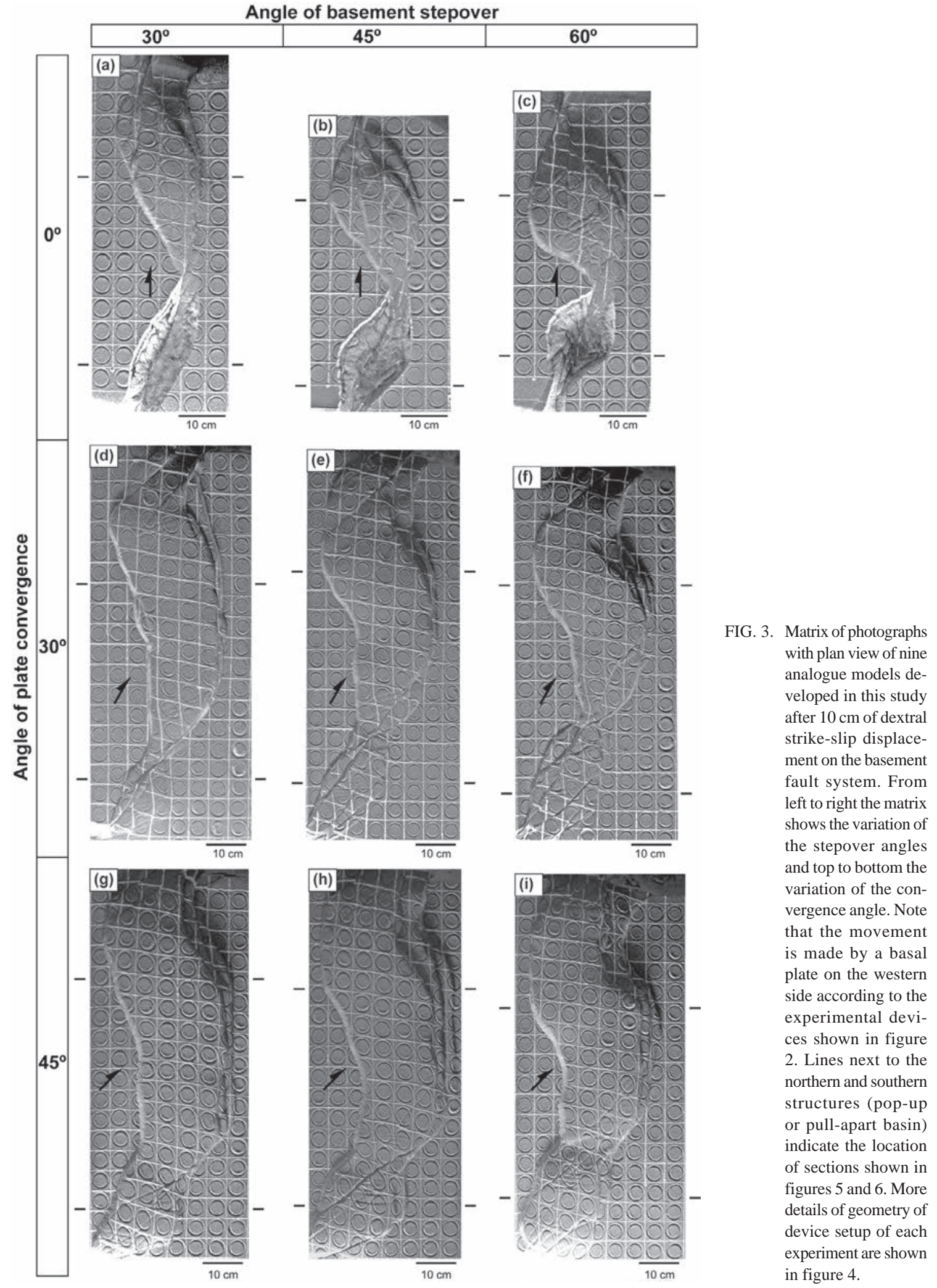




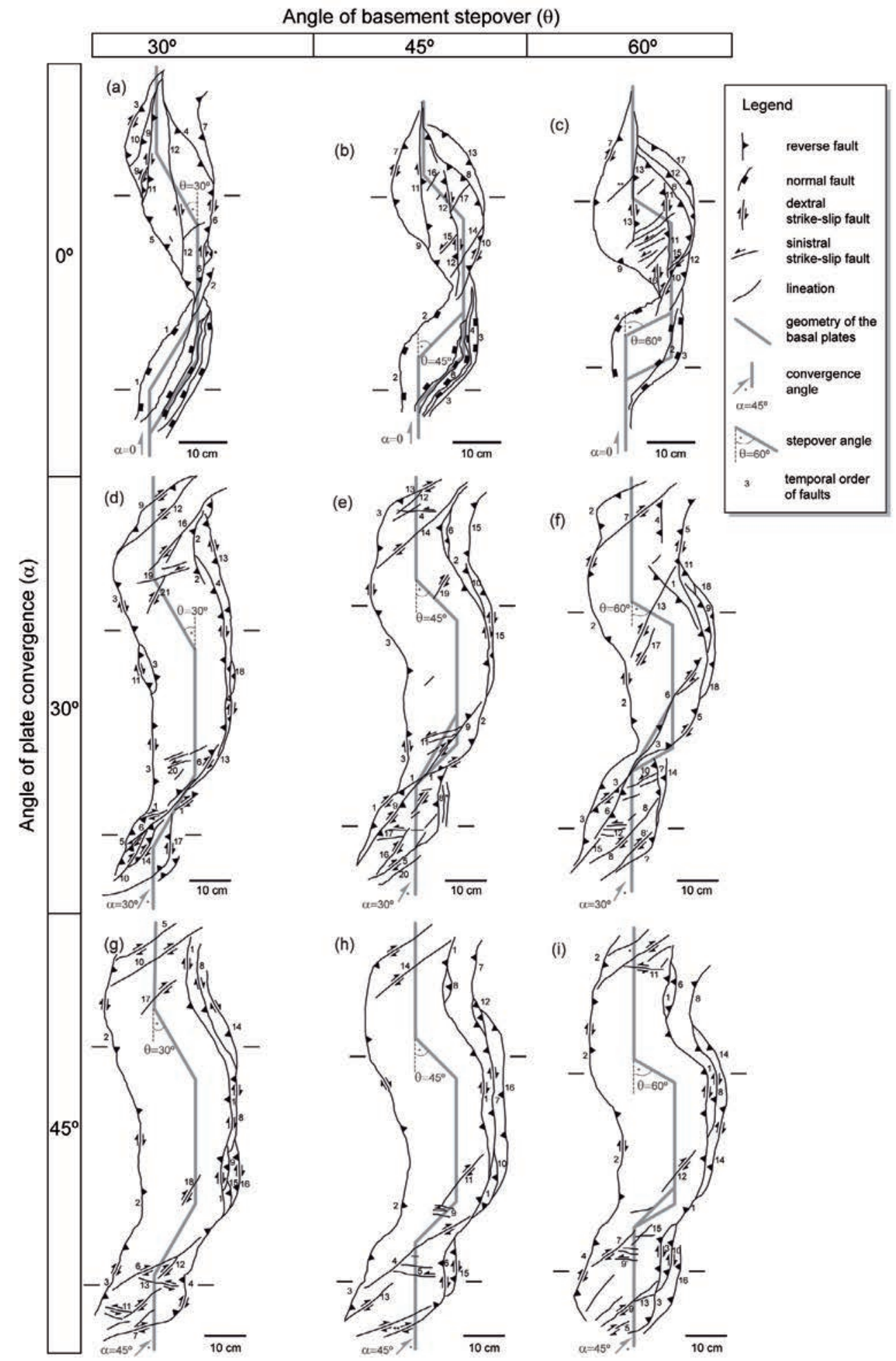

FIG. 4. Matrix of schematic figures of the final structures in plan view of analogue experiments developed in this study. Labels of experiment and location of sections are the same as in figure 3. 
eastwards; while the faults of the pull-apart basin were spread westwards (see temporary numeration of faults in Fig. 4a-c). Furthermore, and in general, the western structures were generated at the beginning of the experiment (ca. 5-40\% of piston displacement) compared to the eastern structures that were generated later (ca. $60-80 \%$ of piston displacement) (Figs. 4a-c). There were two dextral strike-slip, N-S oriented faults in the pop-up following the basement discontinuities and developed later (40-60\% of piston displacement) with respect to the main reverse faults on the borders (e.g., faults 11 and 12 in Fig. 4b). Other minor strike-slip structures, sinistral or dextral, were produced between these faults (Fig. 4a-c). When the pop-up block was fully formed, it had accumulated an average rotation of $11^{\circ}$ clockwise (Table 1$)$.

With higher stepover angles in the set, the geometry of both the pull-apart basin and the pop-up became shorter than the models with lower stepover angles.

Experiment with $30^{\circ}$ stepover. In this experiment (Figs. 3a and 4a), the bulge of the pop-up over the northern stepover appeared earlier than in the other two experiments (b and c in Figs. 3 and 4). Also, the average rotation in the pop-up reached $10^{\circ}$ clockwise (a in Figs. 3, 4 and 5 and Table 1). The pull-apart basin was the shallowest $(4.2 \mathrm{~cm})$ and the longest $(41.3 \mathrm{~cm})$ of the set of experiments (Fig. 6a-c and Table 1). The pop-up had the lowest value of uplift $(1.7 \mathrm{~cm})$ and was the longest $(47.7 \mathrm{~cm})$ of the set (Fig. 5a and Table 1). Thus, the geometry of pop-up and pull-apart basin was more elongated compared to the other two models (Fig. 3a-c and Table 1).

Experiment with $\mathbf{4 5}^{\circ}$ stepover. The eastern limit of the pull-apart basin was characterized by a domino fault array (Figs. 3b, 4b and 6b). Some dextral and sinistral NE oriented strike-slip faults that cut the pop-up block were developed (Fig. 3b; faults 14-17 in Fig. 4b). Another characteristic corresponded to a dextral strike-slip fault with a reverse component of motion that crossed the pop-up from $\mathrm{N}$ to $\mathrm{S}$ (fault 11 in Fig. 4b), stopping the rotations in the eastern block. The average rotation in the pop-up of this experiment was $9^{\circ}$ clockwise (Fig. $3 \mathrm{~b}$ and Table 1 ).

Experiment with $60^{\circ}$ stepover. This experiment presented the highest uplift of the pop-up $(2.1 \mathrm{~cm}$, Table 1$)$, and the deepest $(4.5 \mathrm{~cm}$, Table 1$)$ of the pull-apart basin, with a short rhomboidal geometry in both structures (Figs. 3c, 4c and 6a-c). Moreover, it showed the largest clockwise rotations with an average of $14^{\circ}$ (Fig. 3c and Table 1). In the pop-up of this experiment antithetic sinistral faults were more common (see sinistral faults between faults 11 and 13 in Fig. 4c).

\subsubsection{Set with $30^{\circ}$ convergence angle}

For this set of three experiments (Figs. 3d-f and 4d-f), the second setup described previously was used (Fig. 2b). This setup allowed us to apply an oblique movement to the plates to obtain a transpressionaltranstensional strike-slip system. Below we describe the overall results of the set, followed by the particular characteristics of each experiment.

The set was characterized by the formation of two pop-up blocks (Figs. 3d-f and 4d-f), unlike the previous sets where a southern pull-apart basin was generated. As the stepover angle was higher, the length of the northern pop-up shortened, the southern pop-up lengthened and the flexures of the northern faults became less abrupt than those in the south. The northern pop-up showed a stomach shape and its eastern and western boundaries were parallel to the basal discontinuities (Figs. 3d-f and 4d-f). These boundaries correspond to faults with reverse and dextral strike-slip components (Fig. 5 d-f). The northern and southern limits of the northern pop-up corresponded to reverse and dextral strike-slip faults, respectively. The southern pop-up had a sigmoidal to rhomboidal shape and was bounded by faults with reverse and dextral strike-slip components (Figs. 4d-f and 6d-f).

The development of this set of experiments began with a bulge in the northern block, where the first dextral faults spread to the north and then acquired a reverse component of motion. The bulge of the southern appeared with $40 \%$ of piston displacement through NE strike-slip faults and at this stage reverse faults propagated on the eastern side of the northern pop-up (Fig. 4d-f). With 40-60\% displacement the NE dextral strike-slip faults appeared on the northern pop-up. Once the displacement of the piston (100\% displacement) finished, the northern pop-up had accumulated an average rotation of $10^{\circ}$ clockwise, and the southern pop-up $22^{\circ}$ in the same sense (Figs. 3d-f).

As the stepover angle was higher, the northern pop-up showed a more clearly defined sigmoidalshape and became wider and shorter than in the other experiments (Fig. 4d-f). The southern pop-up was developed longer, wider and higher (Table 1), 


\section{Northern sections}

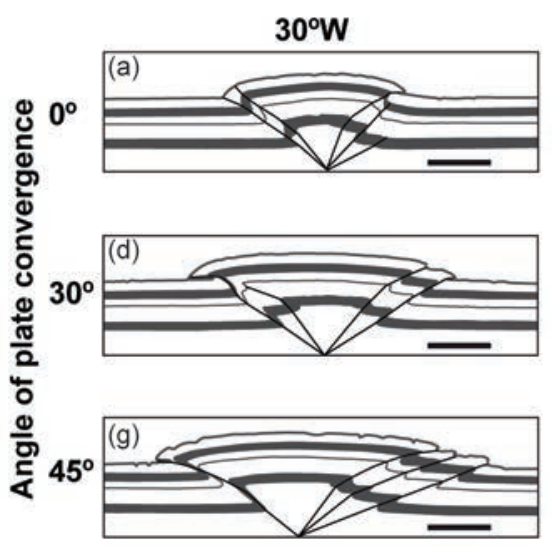

\section{Angle of basement stepover}
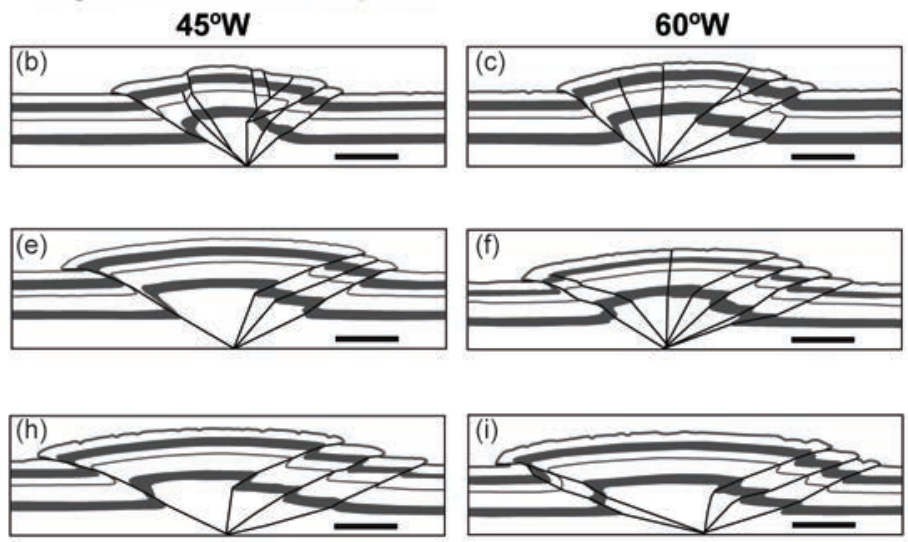

FIG. 5. Matrix with northern structural sections with the final state of the nine studied analogue experiments. See location in figures 3 and 4. From left to right the matrix shows the variation of the stepover angle and from top to bottom the variation of the convergence angle. The black lines represent reverse and strike-slip faults. For simplicity we have not identified the type of faults on the sections. The horizontal bar at the bottom of each section represents a scale of $5 \mathrm{~cm}$.

\section{Southern sections}

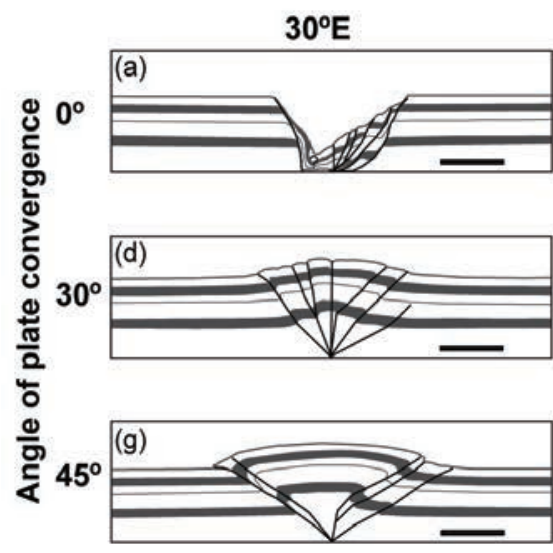

\section{Angle of basement stepover}
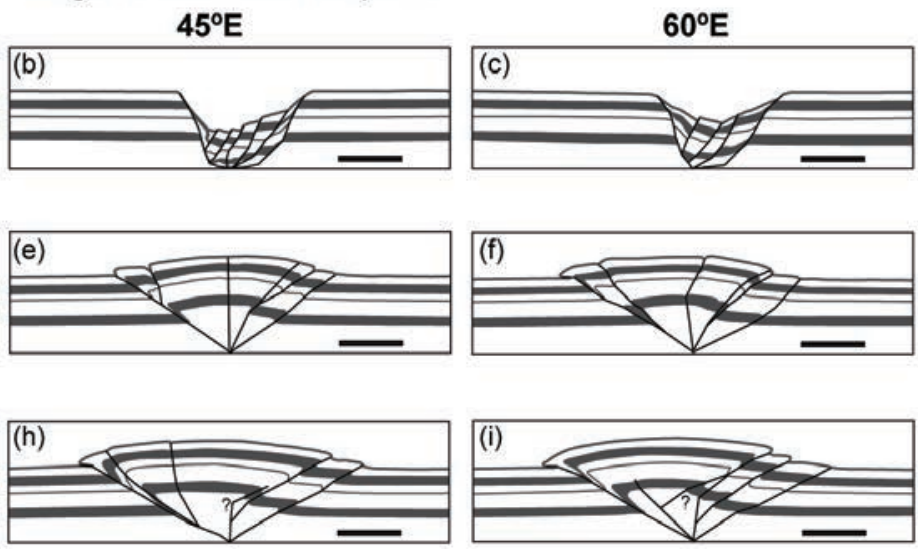

FIG. 6. Matrix with southern structural sections with the final state of the nine studied analogue experiments. See location in figures 3 and 4. Details are similar to figure 5, except that sections a, b and c represent faults with a normal component of motion.

and a series of sinistral strike-slip faults emerged due to rearrangement that spread into the center of the model, being of greater density in the southern block (Fig. 4d-f).

Experiment with $30^{\circ}$ stepover. The development of the northern bulge and faults were the earliest in the set (Fig. 4d). Rotations reached $8^{\circ}$ clockwise for the northern pop-up and $15^{\circ}$ for the southern pop-up, constituting the lowest values of the set (Fig. 3d and Table 1). The geometry of the northern pop-up was the longest $(81.3 \mathrm{~cm})$ as well as the narrowest $(23.9 \mathrm{~cm})$ of the set (Table 1$)$. The southern pop-up was the shortest $(20.3 \mathrm{~cm})$ of this set (Fig. 3d and Table 1). 
Experiment with $\mathbf{4 5}^{\circ}$ stepover. In this experiment (Figs. 3e and 4e), the first fault was formed closer to the discontinuity of the basement than in the previous experiment, and there were an increased number of en-echelon strike-slip faults. Here the northern popup had the lowest uplift of the set $(2 \mathrm{~cm})$ (Table 1$)$. The average rotation reached $10^{\circ}$ clockwise for the northern pop-up and $25^{\circ}$ in the same sense for the southern pop-up (Fig. 3e and Table 1).

Experiment with $\mathbf{6 0}^{\circ}$ stepover. In this experiment (Figs. 3f and 4f), the northern pop-up was shortest $(66.6 \mathrm{~cm})$ and widest $(27.3 \mathrm{~cm})$ of the set (Fig. 4d, e), and the southern pop-up was the longest $(30 \mathrm{~cm})$, widest $(16.8 \mathrm{~cm})$ and with the highest uplift $(1.7 \mathrm{~cm})$ (Figs. 3f and 6f, and Table 1). Broadly, this experiment suffered the largest average rotation of the set, reaching $13^{\circ}$ clockwise in the northern pop-up and $25^{\circ}$ clockwise for the southern pop-up (Fig. 3f).

\subsubsection{Set with $45^{\circ}$ convergence angle}

As in the previous group of experiments, for this set the second setup was used (Fig. 2b), obtaining a transpressional-transtensional strike-slip system more angled than the previous sets.

This set was also characterized by the generation of two pop-ups (Figs. 3g-i and 4g-i). The northern pop-up was stomach-shaped, and its bounding faults were NE to NNE oriented, consisting of dextral strike-slip faults, some with a reverse component (Figs. 4g-i and 5g-i). Faults were cut by dextral strike-slip faults of NE direction. The southern popup was sigmoidal to rhomboidally shaped, and its bounding faults had dextral strike-slip and reverse components, except in the area further south where the block was affected by boundary conditions (Figs. 4g-i and 6g-i).

This experiment started with the appearance of a bulge along the whole model, followed by the formation of faults along the edge of the pop-ups (20\% of piston displacement). These faults had a dextral strike-slip followed by reverse components of motion. They emerged preferably in the northern part of the model and they later extended to the south (Fig. 4 g-h-i). At about $40 \%$ of piston displacement, the first fault that accommodated the global NE dextral shear emerged within the northern pop-up (Fig. 4 g-h-i). Approximately at this stage, reverse faults propagated eastwards on the eastern border of the northern pop-up and some strike-slip faults on both pop-ups were developed (Fig. 4 g-h-i). After piston movement, the northern pop-up had accumulated $10^{\circ}$ clockwise rotation, and the southern pop-up $18^{\circ}$ clockwise rotation (Fig. 3g-i).

As the stepover angle increased through the set, the geometry of the northern pop-up became less elongated and presented a higher rotation, whereas the southern pop-up geometry became more elongated and its rotation was lower (Figs. 3g-i and 4g-i).

Experiment with $30^{\circ}$ stepover. The northern pop-up was the longest $(78 \mathrm{~cm})$, narrowest $(28 \mathrm{~cm})$ and with the lowest uplift $(2.1 \mathrm{~cm})$ of the set (Figs. $3 g, 4 g$ and $5 g$ and Table 1), while the southern pop-up was the shortest $(23 \mathrm{~cm}$ ) (g-i in Figs. 3, 4 and 6 and Table 1). Likewise, the average rotation achieved $7^{\circ}$ clockwise for the northern pop-up, being the lowest value of the set. On the contrary, the average rotation for the southern pop-up was $22^{\circ}$ clockwise, being the highest one of the set (Fig. $3 g$ and Table 1). The en-echelon faults were distributed from the limits of the pop-up to the center of the experiment and were generated during the last stage of deformation.

Experiment with $\mathbf{4 5}^{\circ}$ stepover. This experiment was characterized by the fact that the last faults were generated along the eastern boundaries of the popups. The northern pop-up accumulated an average of $10^{\circ}$ clockwise rotation and the southern pop-up $18^{\circ}$ in the same sense (Fig. 3h).

Experiment with $\mathbf{6 0}^{\circ}$ stepover. In this experiment (Figs. 3i and 4i), the northern pop-up was the widest $(32.6 \mathrm{~cm})$ and the shortest $(71.5 \mathrm{~cm})$ (Figs. $3 i, 4 i$ and $5 i)$ of this set and the southern pop-up was the longest $(32.2 \mathrm{~cm})$, widest $(19.7 \mathrm{~cm})$ and with the highest average uplift $(2.3 \mathrm{~cm}$ ) (i in Figs. 3, 4 and 6 and Table 1). With regard to the vertical axis rotations, the northern pop-up had the highest rotations, being $12^{\circ}$ clockwise, and the southern pop-up had the lowest rotation, reaching $15^{\circ}$ in the same sense (Fig. 3i and Table 1).

\subsubsection{Cross-analysis of the sets}

Based on the obtained results (Table 1), we generated a data matrix where we take the convergence angle as a variable to analyze the evolution of strikeslip systems. Thus, the following discussion provides another evolutionary perspective by comparing the experiments with identical stepover angle (Figs. 3, 4, 5 and 6: $\left.30^{\circ}=\mathrm{a}, \mathrm{d}, \mathrm{g} ; 45^{\circ}=\mathrm{b}, \mathrm{e}, \mathrm{h} ; 60^{\circ}=\mathrm{c}, \mathrm{f}, \mathrm{i}\right)$.

Experiments with $30^{\circ}$ stepover. For the experiments with $30^{\circ}$ stepover (a, d and $g$ in Figs. 3 and 4 ), in the northern area a pop-up was formed. As the convergence angle was higher, the number of 
TABLE 1. STRAIN DATA FROM ANALOGUE EXPERIMENTS DEVELOPED IN THIS STUDY.

\begin{tabular}{|c|c|c|c|c|c|}
\hline \multirow{16}{*}{ 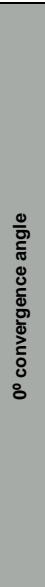 } & \multicolumn{2}{|l|}{ Zone } & \multirow{2}{*}{\begin{tabular}{|l|}
$30^{\circ}$ stepover \\
16.3 \\
\end{tabular}} & \multirow{2}{*}{\begin{tabular}{|l|}
$45^{\circ}$ stepover \\
19 \\
\end{tabular}} & \multirow{2}{*}{\begin{tabular}{|l}
$60^{\circ}$ stepover \\
24.2
\end{tabular}} \\
\hline & Pop-up & Width $(\mathrm{cm})$ & & & \\
\hline & & Lenght $(\mathrm{cm})$ & 47.7 & 43.8 & 40.1 \\
\hline & & Uplift $(\mathrm{cm})$ & 1.7 & 1.9 & 2.1 \\
\hline & & Rotation & $10^{\circ}$ clockwise & $9^{\circ}$ clockwise & $14^{\circ}$ clockwise \\
\hline & & Structures: & & & \\
\hline & & $\mathrm{NE}$ & \begin{tabular}{|l|l|} 
Imbricate reverse faults, NNW \\
oriented, E-NE vergent
\end{tabular} & \begin{tabular}{|l|l|} 
Imbricate reverse faults, NW \\
oriented and NE vergent
\end{tabular} & \begin{tabular}{|lll} 
Imbricate reverse faults, NW \\
oriented and NE vergent
\end{tabular} \\
\hline & & SE & \begin{tabular}{|l|l|}
$\begin{array}{l}\text { Dextral strike-slip faults, with } \\
\text { reverse component }\end{array}$ \\
\end{tabular} & $\begin{array}{l}\text { Reverse fault E vergent, with dextral } \\
\text { strike-slip component }\end{array}$ & $\begin{array}{l}\text { Reverse fault E vergent, with dextral } \\
\text { strike-slip component }\end{array}$ \\
\hline & & SW & $\begin{array}{l}\text { Reverse fault, NW oriented and SW } \\
\text { vergent }\end{array}$ & \begin{tabular}{|l|} 
Reverse fault SW vergent \\
\end{tabular} & Reverse fault SW vergent \\
\hline & & NW & \begin{tabular}{|l|} 
Reverse faults NW vergent, with \\
dextral strike-slip component
\end{tabular} & $\begin{array}{l}\text { Reverse fault NW vergent, with } \\
\text { dextral strike-slip component }\end{array}$ & \begin{tabular}{|l|l|} 
Reverse fault NW vergent, with \\
dextral strike-slip component
\end{tabular} \\
\hline & Pull-apart & Width $(\mathrm{cm})$ & \begin{tabular}{|l|l|}
10.8 & \\
\end{tabular} & \begin{tabular}{|l|l|}
14.3 & \\
\end{tabular} & 14.7 \\
\hline & & Lenght $(\mathrm{cm})$ & 41.3 & 32.3 & 22 \\
\hline & & Depth $(\mathrm{cm})$ & 4.2 & 4.3 & 4.5 \\
\hline & & Structures: & & & \\
\hline & & W & $\begin{array}{l}\text { Normal fault dipping } 50^{\circ} \mathrm{E} \text {, around } \\
\mathrm{NE} \text { oriented, with dextral strike-slip } \\
\text { component }\end{array}$ & $\begin{array}{l}\text { Normal fault dipping } 45^{\circ} \mathrm{W}, \mathrm{NE} \text { and } \\
\mathrm{N} \text {-S oriented, with dextral strike-slip } \\
\text { component }\end{array}$ & $\begin{array}{l}\text { Normal fault dipping } 50^{\circ} \mathrm{E}, \mathrm{NE} \text { and } \\
\mathrm{N}-\mathrm{S} \text { oriented, with dextral strike-slip } \\
\text { component }\end{array}$ \\
\hline & & E & \begin{tabular}{|l|} 
Domino set of 4 normal faults \\
dipping $60^{\circ} \mathrm{W}, \mathrm{N}-\mathrm{S}$ and NE oriented, \\
with dextral strike-slip component
\end{tabular} & \begin{tabular}{|l|} 
Domino set of 5 normal faults \\
dipping $60^{\circ} \mathrm{W}, \mathrm{N}-\mathrm{S}$ and NE oriented, \\
with dextral strike-slip component
\end{tabular} & \begin{tabular}{|l|} 
Domino set of 2 normal faults \\
dipping $60^{\circ} \mathrm{W}, \mathrm{N}-\mathrm{S}$ and NE oriented, \\
with dextral strike-slip component
\end{tabular} \\
\hline \multirow{18}{*}{ 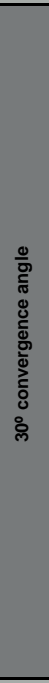 } & Pop-up N & Width $(\mathrm{cm})$ & 23.9 & 26 & 27.3 \\
\hline & & Lenght $(\mathrm{cm})$ & 81.3 & 74 & 66.6 \\
\hline & & Uplift $(\mathrm{cm})$ & 2.2 & 2.0 & 2.2 \\
\hline & & Rotation & $8^{\circ}$ clockwise & $10^{\circ}$ clockwise & $13^{\circ}$ clockwise \\
\hline & & Structures: & & & \\
\hline & & $\mathrm{N}$ & \begin{tabular}{|l|l|}
$\begin{array}{l}\text { Dextral strike-slip faults, with } \\
\text { reverse component }\end{array}$ \\
\end{tabular} & $\begin{array}{l}\text { Reverse fault W-NE vergent, with } \\
\text { dextral strike-slip component }\end{array}$ & \begin{tabular}{|l|} 
Reverse fault $\mathrm{W}$ and $\mathrm{N}$ vergent and \\
$\mathrm{NE}$ dextral strike-slip fault
\end{tabular} \\
\hline & & E & \begin{tabular}{|l|}
$\begin{array}{l}\text { Reverse fault E vergent, with dextral } \\
\text { strike-slip component }\end{array}$ \\
\end{tabular} & \begin{tabular}{|l|} 
Reverse faults $E$ vergent, with \\
dextral strike-slip component
\end{tabular} & \begin{tabular}{|l|l|} 
Reverse faults E vergent, with \\
dextral strike-slip component
\end{tabular} \\
\hline & & $\mathrm{s}$ & \begin{tabular}{|l|} 
Reverse and dextral strike-slip \\
faults, NE oriented and SW vergent \\
\end{tabular} & $\begin{array}{l}\text { Reverse fault, } \mathrm{N} \text { and } \mathrm{S} \text { vergent, with } \\
\text { dextral strike-slip component }\end{array}$ & $\begin{array}{l}\text { Reverse fault } \mathrm{E} \text { and } \mathrm{N} \text { vergent with } \\
\text { dextral strike-slip component }\end{array}$ \\
\hline & & W & \begin{tabular}{|l|l|} 
Dextral strike-slip faults, with \\
reverse component W vergent
\end{tabular} & \begin{tabular}{|l|l|} 
Reverse fault W vergent, with \\
dextral strike-slip component
\end{tabular} & $\begin{array}{l}\text { Reverse fault W and SW vergent, } \\
\text { with dextral strike-slip component }\end{array}$ \\
\hline & Pop-up S & Width (cm) & 14 & \begin{tabular}{|l|l|}
14.3 & \\
\end{tabular} & 16.8 \\
\hline & & Lenght $(\mathrm{cm})$ & 20.3 & 28.3 & 30 \\
\hline & & Uplift $(\mathrm{cm})$ & 1.2 & 1.2 & 1.7 \\
\hline & & Rotation & $15^{\circ}$ clockwise & $25^{\circ}$ clockwise & $25^{\circ}$ clockwise \\
\hline & & Structures: & & & \\
\hline & & $\mathrm{N}$ & \begin{tabular}{|l|l|} 
Dextral strike-slip faults, NE \\
oriented and NW vergent
\end{tabular} & $\begin{array}{l}\text { Reverse fault, } \mathrm{N} \text { and } \mathrm{S} \text { vergent, with } \\
\text { dextral strike-slip component }\end{array}$ & $\begin{array}{l}\text { Reverse fault, } \mathrm{NE} \text { oriented, NW } \\
\text { vergent, with dextral strike-slip } \\
\text { component }\end{array}$ \\
\hline & & $\mathrm{E}$ & \begin{tabular}{|l|}
$\begin{array}{l}\text { Reverse fault, curved and E and SE } \\
\text { vergent }\end{array}$ \\
\end{tabular} & \begin{tabular}{|l}
$\begin{array}{l}\text { Reverse fault, N-S oriented, E } \\
\text { vergent }\end{array}$ \\
\end{tabular} & \begin{tabular}{|l}
$\begin{array}{l}\text { Reverse fault, } \mathrm{N}-\mathrm{S} \\
\text { vergent }\end{array}$ \\
\end{tabular} \\
\hline & & $\mathrm{S}$ & \begin{tabular}{|l|}
$\begin{array}{l}\text { Reverse fault, curved and } \mathrm{E} \text { and SE } \\
\text { vergent }\end{array}$ \\
\end{tabular} & Dextral strike-slip fault, NE oriented & Dextral strike-slip fault, NE oriented \\
\hline & & W & \begin{tabular}{|l|}
$\begin{array}{l}\text { Reverse fault, NE oriented and } \mathrm{W} \\
\text { vergent }\end{array}$ \\
\end{tabular} & \begin{tabular}{|ll}
$\begin{array}{l}\text { Reverse fault, NE oriented, NW } \\
\text { vergent with dextral strike-slip } \\
\text { component }\end{array}$ & \\
\end{tabular} & $\begin{array}{l}\begin{array}{l}\text { Reverse faults, N-S oriented, W } \\
\text { vergent }\end{array} \\
\end{array}$ \\
\hline \multirow{18}{*}{ 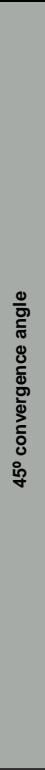 } & Pop-up N & Width $(\mathrm{cm})$ & 28 & 29.4 & 32.6 \\
\hline & & Lenght $(\mathrm{cm})$ & 78 & 76.1 & 71.5 \\
\hline & & Uplift (cm) & 2.1 & 2.4 & 2.4 \\
\hline & & Rotation & $7^{\circ}$ clockwise & $10^{\circ}$ clockwise & $12^{\circ}$ clockwise \\
\hline & & Structures: & & & \\
\hline & & $\mathrm{N}$ & $\begin{array}{|lll|}\begin{array}{l}\text { Dextral } \\
\text { oriented }\end{array} & \text { strike-slip faults, NE } \\
\end{array}$ & $\begin{array}{|lll|}\begin{array}{l}\text { Dextral } \\
\text { oriented }\end{array} & \text { strike-slip faults, NE } \\
\end{array}$ & \begin{tabular}{|llll}
$\begin{array}{l}\text { Dextral } \\
\text { oriented }\end{array}$ & strike-slip faults, & $\mathrm{NE}$ \\
\end{tabular} \\
\hline & & $E$ & $\begin{array}{l}\text { Reverse faults, around N-S oriented } \\
\text { and E vergent, with dextral strike- } \\
\text { slip component }\end{array}$ & $\begin{array}{l}\text { Reverse faults, curved, around N-S } \\
\text { oriented and E vergent, with dextral } \\
\text { strike-slip component }\end{array}$ & $\begin{array}{l}\text { Reverse faults, curved, around N-S } \\
\text { oriented and E vergent, with dextral } \\
\text { strike-slip component }\end{array}$ \\
\hline & & $\mathrm{S}$ & $\begin{array}{|lll|}\begin{array}{l}\text { Dextral } \\
\text { oriented }\end{array} & \text { strike-slip fault, ENE } \\
\end{array}$ & \begin{tabular}{|l|} 
Dextral strike-slip fault, NE oriented \\
\end{tabular} & $\begin{array}{l}\text { Reverse fault, NE vergent and SE } \\
\text { vergent, and dextral strike-slip fault, } \\
\text { NE oriented }\end{array}$ \\
\hline & & W & $\begin{array}{l}\text { Reverse fault, N-S oriented and } \mathrm{W} \\
\text { vergent, with dextral strike-slip } \\
\text { component }\end{array}$ & $\begin{array}{l}\text { Reverse fault, curved, around } \mathrm{N}-\mathrm{S} \\
\text { oriented and } \mathrm{W} \text { vergent, with dextral } \\
\text { strike-slip component }\end{array}$ & $\begin{array}{l}\text { Reverse fault, curved, around } \mathrm{N}-\mathrm{S} \\
\text { oriented and } \mathrm{W} \text { vergent, with dextral } \\
\text { strike-slip component }\end{array}$ \\
\hline & Pop-up S & Width $(\mathrm{cm})$ & 16 & \begin{tabular}{|l|l|}
18 & \\
\end{tabular} & 19.7 \\
\hline & & Lenght $(\mathrm{cm})$ & 23 & 31.4 & 32.2 \\
\hline & & \begin{tabular}{|l|} 
Uplift $(\mathrm{cm})$ \\
\end{tabular} & 1.8 & 1.8 & 2.3 \\
\hline & & Rotation & $22^{\circ}$ clockwise & $18^{\circ}$ clockwise & $15^{\circ}$ clockwise \\
\hline & & Structures: & & & \\
\hline & & $\mathrm{N}$ & $\begin{array}{|llll|}\begin{array}{l}\text { Dextral } \\
\text { oriented }\end{array} & \text { strike-slip fault, } & \text { ENE } \\
\end{array}$ & Dextral strike-slip fault, NE oriented & $\begin{array}{l}\text { Dextral strike-slip fault, NE oriented } \\
\text { and others minors sinistral strike- } \\
\text { slip faults }\end{array}$ \\
\hline & & $\mathrm{E}$ & \begin{tabular}{|l|}
$\begin{array}{l}\text { Reverse fault, curved and } \mathrm{E} \text { and } \mathrm{SE} \\
\text { vergent }\end{array}$ \\
\end{tabular} & $\begin{array}{l}\text { Reverse faults, N-S oriented, E } \\
\text { vergent, with dextral strike-slip } \\
\text { component }\end{array}$ & $\begin{array}{l}\text { Reverse faults, N-S oriented, E } \\
\begin{array}{l}\text { vergent, with dextral strike-slip } \\
\text { component }\end{array}\end{array}$ \\
\hline & & $\mathrm{s}$ & \begin{tabular}{|llll}
$\begin{array}{l}\text { Dextral } \\
\text { oriented }\end{array}$ & strike-slip fault, ENE \\
\end{tabular} & $\begin{array}{|lll|}\begin{array}{l}\text { Dextral } \\
\text { oriented }\end{array} & \text { strike-slip faults, } \quad \mathrm{NE} \\
\end{array}$ & \begin{tabular}{|lll} 
Dextral strike-slip faults, & $\mathrm{NE}$ \\
oriented, and reverse faults & $\mathrm{NE}$ \\
oriented and SE vergent & & \\
\end{tabular} \\
\hline & & W & \begin{tabular}{|l|} 
Reverse fault, $\mathrm{NE}$ oriented, W \\
vergent, with strike-slip component
\end{tabular} & \begin{tabular}{|l|} 
Reverse fault, NE oriented, W \\
vergent, with strike-slip component
\end{tabular} & $\begin{array}{l}\text { Reverse fault, NE oriented, W } \\
\text { vergent, with strike-slip component }\end{array}$ \\
\hline
\end{tabular}


reverse faults along the NE boundary of this block also increased (a, d and $g$ in Figs. 4 and 5). Depending on the convergence angle, the structure that formed in the southern area had major differences; only in the case of a $0^{\circ}$ convergence angle a pull-apart basin formed (Figs. 3a, 4a and 6a). In the other two cases (convergence angles of $30^{\circ}$ and $45^{\circ}$ ) a bigger northern pop-up and a southern pop-up were developed with a complex array of reverse and strike-slip faults (d and $g$ in Figs. 3, 45 and 6). In addition, with higher convergence angles the northern pop-up tended to lose its sigmoidal shape taking a shape of a stomach. This is explained by a greater convergence angle than the stepover angle generating a bigger transpressional zone (Figs. 4d and 4g).

Rotations were inversely proportional $\left(10^{\circ}, 8^{\circ}\right.$ and $7^{\circ}$ clockwise) to the increment of the convergence angle $\left(0^{\circ}, 30^{\circ}\right.$ and $45^{\circ}$, respectively), unlike the uplift $(1.7,2.2$ and $2.1 \mathrm{~cm})$ which was directly proportional (Table 1).

Experiments with $4^{\circ}$ stepover. For $45^{\circ}$ stepover, the three experiments (b, e and h in Figs. 3, 4 and 5) showed a northern pop-up and, as in the above analysis, reflected an increment in the number of faults at the NE limit with increasing convergence angle. Similarly, in the southern part of the experiment a pull-apart basin was formed only with a convergence of $0^{\circ}(\mathrm{b}$ in Figs. 3, 4 and 6).The northern and southern pop-ups in experiments with $30^{\circ}$ and $45^{\circ}$ convergence angles were also characterized by complex strike-slip and reverse faults (e, h in Figs. 4, 5 and 6). Besides, the northern pop-up tended to be bigger and stomach-shaped than that of $30^{\circ}$ convergence angle (e, h in Figs. 3 and 4).

The rotations were inversely proportional $\left(9^{\circ}\right.$, $10^{\circ}$ and $10^{\circ}$ clockwise) to the convergence angle $\left(0^{\circ}, 30^{\circ}\right.$ and $45^{\circ}$, respectively), different from the uplift that had a direct relationship (1.9, 2.0 and 2.4 cm) (Table 1).

Experiments with $60^{\circ}$ stepover. For the models with $60^{\circ}$ stepover (c, $\mathrm{f}$ and $\mathrm{i}$ in Figs. 3 and 4), a pop-up in the northern zone was produced which concentrated most of the faults at its NE side, and which was progressively bigger and stomach-shaped to higher convergence angles. The geometry of the southern area was similar to the previous set, with a pull-apart basin at $0^{\circ}$ convergence angle and a pop-up at others angles $\left(30^{\circ}\right.$ and $\left.45^{\circ}\right)$ (c, f, i in Figs. 3, 4, 5 and 6). The antithetical faults in this block developed towards the boundaries experiment with an increasing of the convergence angle (c, f, i in Fig. 4).

As in the previous analysis, the rotations were inversely proportional $\left(14^{\circ}, 13^{\circ}\right.$ and $12^{\circ}$ clockwise $)$ and the uplift was directly proportional (2.1, 2.2 and $2.4 \mathrm{~cm}$ ) to the variation of the convergence angle $\left(0^{\circ}, 30^{\circ}\right.$ and $45^{\circ}$, respectively) (Table 1$)$.

\subsubsection{Summary of results}

The overall results of analogue experiments indicate that the geometry of antiformal pop-up structures and pull-apart basins are directly related to basement structures by the geometry of stepovers. If the stepover is high-angled with respect to the global strike-slip system, the pop-up or pull-apart basin will have a short rhomboidal to sigmoidal geometry, and conversely if stepover has a smaller angle related to the global system, the geometries will be more elongated. Similar results have been shown for pull-apart basins in recent studies, but that analyzed only the case of a stepover of $30^{\circ}$ (Wu et al., 2009).

In addition, in all the strike-slip fault systems with antiformal pop-up structures, dextral faults (synthetic Riedel R) tend to be parallel to the main stress system defined by the convergence angle. There will be antithetic faults (R') perpendicular to the stepover.

For the northern pop-up an increase the stepover angle, independent of the convergence angle, resulted in a higher rotation. This suggests that if stepover forms a high angle (with a maximum of $90^{\circ}$ ) in relation to the global strike-slip system (N-S in the studied case), the formed blocks will rotate more.

For these pop-ups, only in the case of pure convergence (first set with $0^{\circ}$ convergence angle), there was a higher uplift related to a higher stepover angle. This could be explained by a higher angle of the main stress vector with respect to the stepover and, therefore, favored the development of reverse faults parallel to these basal structures.

Moreover, a higher convergence angle produced more uplift and less rotation for the northern popups. Hence, by increasing the convergence angle the basal structure became more perpendicular to the principal stress vector (Figs. 3 and 4) and thus, the global shortening was absorbed mainly by reverse faults parallel to the basal discontinuities. As the deformation was absorbed mainly by reverse faults less strike-slip faults were developed, then fewer blocks were formed so they could rotate more linked to a greater uplift. 


\section{Numerical Restoration}

\subsection{Methodology}

The digital restoration applied in this study corresponds to the classical method described in the literature (e.g., Arriagada et al., 2008). It is based on the removal of the horizontal components of motion in the boundary faults of the tectonic blocks by the method of least squares in the gaps between blocks or overlaps between them (e.g., Rouby et al., 1993; Bourgeois et al., 1997). A modified method was used by Arriagada et al. (2008), where the minimization of inter-block and overlap areas are arranged in 30 to 60 steps for each movement, making it more stable numerically. This model uses three main parameters for its construction: a. the block geometry and its spatial relation to contiguous blocks; b. the shortening data, defined by the area decrease in percentage of the block determined by the strain ellipse; and c. the rotational data, defined by the grid lines rotation from the block in the analogue model.

The method of numerical restoration was applied to the area of the northern pop-up of the first model of the first set (Figs. 3a, $4 \mathrm{a}$ and 7 ), i.e., $0^{\circ}$ convergence angle and $30^{\circ}$ restraining stepover.

For the restoration, the upper sand level was chosen, thus producing a map of the tectonic blocks (Fig. 7). The large blocks were divided into smaller blocks using artificial boundaries (Fig. 7). Using this division we chose two large blocks, block 41 and block 1 (Fig. 7), to use as a reference in following the continuous movement. Block 1 moved according to the input data in the model, and block 41 remained without movement in the numerical restoration. These blocks were chosen by their low internal deformation (Fig. 7). With these parameters, we obtained a general numerical representation of the analyzed analogue model, having for each block shortening data, rotational data and its spatial relation to contiguous blocks. The 'shortening data' will correspond to a quantity and direction of shortening of blocks and the 'rotational data' correspond to a quantity and a sense of rotation of blocks. Thus, the numerical model will be linked to these three parameters for each block.

The numerical restoration comprised $n$ iterations ( $n=30-60)$, with each iteration composed of three stages for each block. These stages are a. a block expansion, which restores a fraction of shortening; b. a fraction of rotation in the opposite direction of the rotational input data; c. an analysis of the contiguous blocks in order to minimize the overlap between blocks. These steps are repeated cyclically until the iterations are done.

During the restoration process, block 1 was moved to the 'north' in order to restore the analogue experiment. This block had a progress limit of $10 \mathrm{~cm}$ in order to reach a similar distance than the traveled by the real block in the sandbox model. To obtain this movement, each block was expanded and rotated towards its original position before deformation, using the shortening and the rotational data, in a minimal fraction in each iteration. The software determined the overlaps between blocks, trying to minimize them and maintaining its adjoining blocks.

\section{(a)}

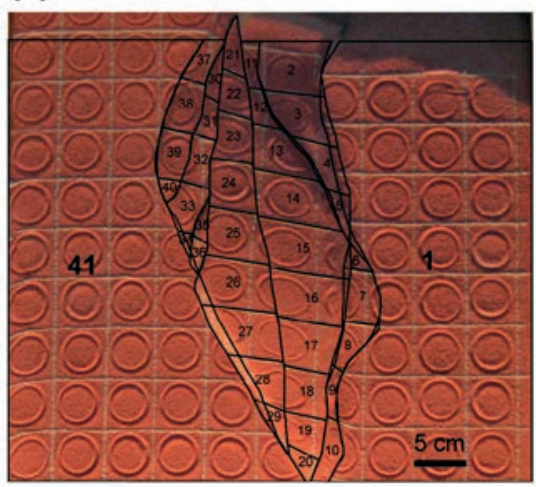

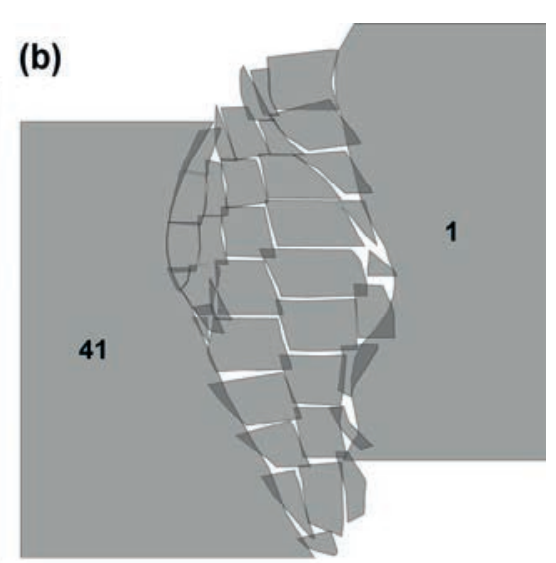

FIG. 7. a. Analogue model of the analyzed case of $0^{\circ}$ convergence angle and $30^{\circ}$ stepover (see figures $3 a$ and $4 a$ ), with identification of blocks to be restored; $\mathbf{b}$. Restored model in which $100 \%$ shortening and rotational data were used. 


\subsection{Results and sensibility analysis}

Numerical analysis of the sandbox model was performed with the purpose of understanding the main parameters that affect the development of a strike-slip system and their degree of influence. A series of numerical models were designed with a variable amount of parameters, different percentages of global shortening and rotational data, in order to recognize the main characteristics that best fit the numerical model of the sandbox model (Figs. 3 and 5). Different numerical models were obtained, and thus a matrix was constructed for the type and percentage of data used (Fig. 8). When these numerical models were fed with half of any dataset, these data corresponded to the left-hand side blocks of the model (as from block 21, Fig. 7). The fit of each numerical model was analyzed in terms of the percentage error of block 1 displacement related to the original sandbox model and the blocks overlaps and gaps in percentage (Figs. 7 and 8).

An important observation from all numerical models was that the percentage of gaps and overlaps were fairly low, in the order of 1-3\%. Despite this, we noted that the model fit depended on the shortening and/or rotational data input. The results of this analysis are given below.

The absence of shortening data in the first set of numerical models (Fig. 8a-d) impacted on the movement of the restored block 1 , which had a sense of movement and/or distance very different to its real movement. Thus, block 1 had a more irregular progress compared to the others sets of numerical models. As a consequence, the average error in the displacement of block 1 in this set was the largest (86.75\%, Table 2) compared to the other sets (Fig. 8 and Table 2), reaching in one case up to $180 \%$ (Fig. 8c).

The second set of numerical models (Fig. 8e-h) had $25 \%$ of shortening data. The movements of block 1 were more regular than in the set without shortening data (Fig. 8). However, this set had the greatest percentage of gaps as compared with the other sets (2.98\%, Table 2$)$. This can be attributed to the minimal input of shortening data, which caused a destabilization of the distance between the contiguous blocks. This reduced the overlaps and increased the blocks' freedom to rotate or move. Consequently, the average percentage of overlaps was lowest (Fig. 8 and Table 2). Moreover, the average displacement error of block 1 was also very high (34.5\%, Table 2).
The third set of numerical models, with $50 \%$ of shortening data (Fig. 8i-1), showed an increase in the percentage of overlaps with respect to the previous set of numerical models ( $25 \%$ of the shortening data). This is because more shortening data provided further information for the restoration of the blocks. In this case the gaps decreased and therefore the overlaps increased, because there were more chances for the blocks to be closer. Moreover, more shortening data produced a stabilization of block 1's displacement relative to that of the previous sets, substantially reducing the percentage error of block 1's displacement with respect to the sandbox experiment (11.19\%, Table 2).

The fourth set of numerical models, with the total shortening data available (Fig. 8m-o), showed that the percentage of gaps and overlaps is similar regardless of the amount of rotational data. This set shows that the distance covered by block 1 is as stable as the third set and has the lowest average percentage of gaps with respect to the three previous sets $(1.91 \%$, Table 2$)$.

A general view shows that the average percentage of gaps between blocks is directly proportional to the amount of shortening data (Fig. 8), when the set without shortening data is eliminated. Besides, models without data (Fig. 8a-d) have poor control on the tectonic behavior; in some cases block 1 moved in the contrary sense of displacement expected, only considering its geometric boundaries. Moreover, the average percentage of gaps between blocks is inversely proportional to the rotational data (Table 2), when the set without rotational data is ignored. This occurs because more rotational data causes a better fit between blocks.

When we compare the distances covered by block 1 in the different numerical models, the closest to the analyzed analogue experiment are those that possess more shortening and rotational data. The lower errors were associated with $50 \%$ and $100 \%$ of shortening and rotational data (Table 2). In particular, the lowest value was found in the numerical model with $100 \%$ of rotational data and $100 \%$ of shortening data (Fig. 80 and Table 2). Thus, this numerical model generated the best restoration of the sandbox experiment (Fig. 8). However, a high percentage error was obtained in some models of the set with $100 \%$ of shortening data (Fig. 8 and Table 2). It could correspond to overestimates of these data, which lead to an overexpansion of the 


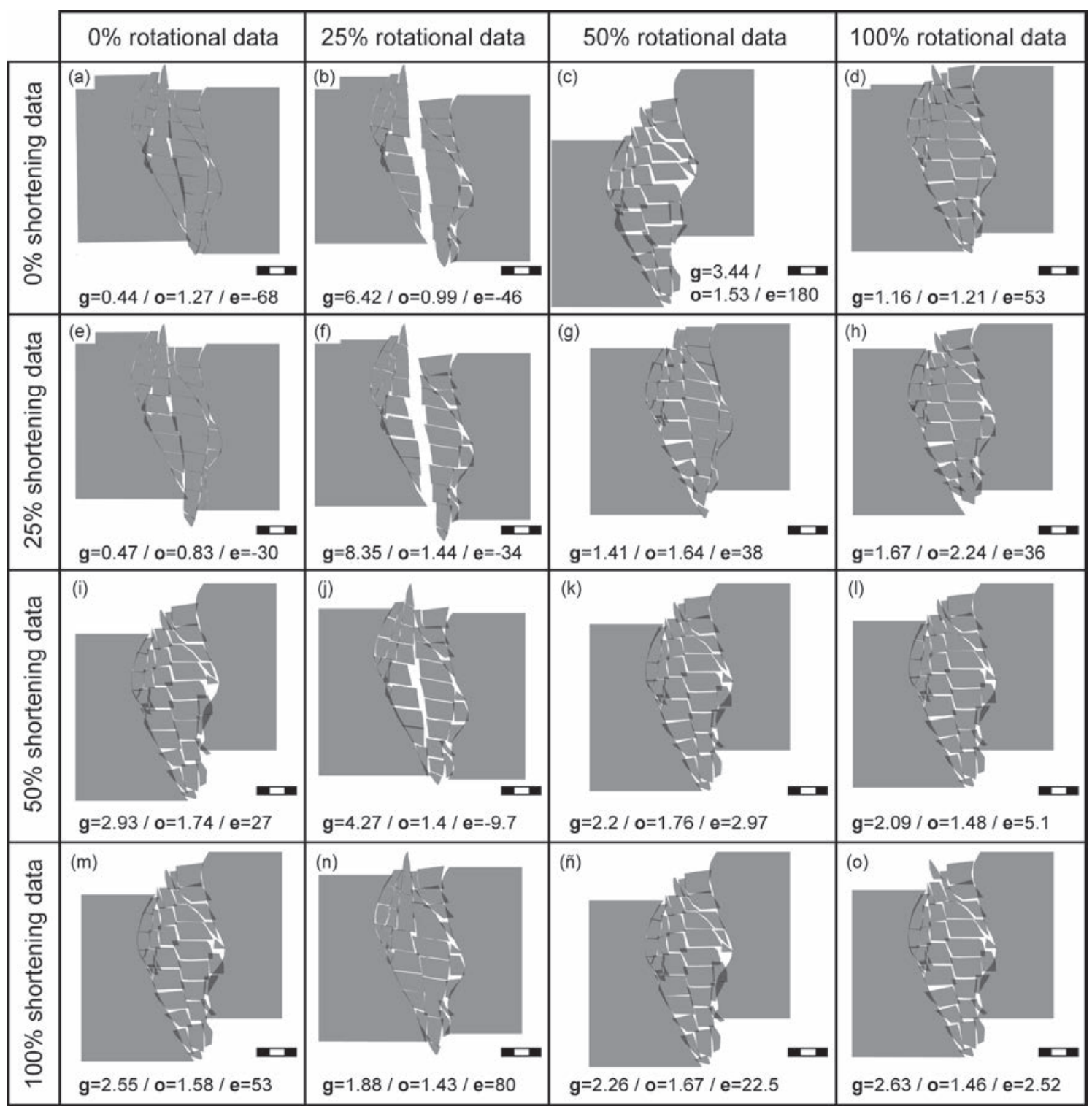

FIG. 8. Matrix models with sensitivity analysis of numerical restoration applied to the case of a $0^{\circ}$ convergence angle and $30^{\circ}$ stepover angle (Figs. 3a and 4a). The nomenclature at the bottom of each numerical model corresponds to ' $\mathbf{g}$ ', the percentage of gaps in the model, 'o', the percentage of overlap between blocks in the model, and 'e', the percentage error of the block 1 's movement with respect to the original block in the sandbox experiment. Blocks 1 and 41 are the same shown in figure 7. A scale of $10 \mathrm{~cm}$ is indicated at the bottom of each numerical model.

blocks, requiring more space to rearrange each other, and therefore accumulating more covered distance.

As explained above, we conclude that shortening data are a very important element required for a numerical restoration of the studied cases of deformation. Without tectonic shortening data we do not have a good control on the expansion of blocks. In this way, they expand excessively and uncontrollably, producing compression among the blocks, which are rearranged by the restoration method to reduce the overlap. These expansions and rearrangements of the blocks produce an increase in distance covered by the block 1 . Thus, this distance is controlled directly by the shortening data that fed the model. This con- 
TABLE 2. RESTORATION DATA USED IN THE NUMERICAL ANALYSIS.

\begin{tabular}{|c|c|c|c|c|c|c|c|}
\hline & & & & & ational & & Average \\
\hline & & & 0\% & $25 \%$ & $50 \%$ & $100 \%$ & shortening \\
\hline & $0 \%$ & overlap & 1,27 & 0,99 & 3,44 & 1,16 & 1,72 \\
\hline & & gaps & 0,44 & 6,42 & 1,53 & 1,21 & 2,40 \\
\hline & & displacement & $-68,00$ & $-46,00$ & 180,00 & 53,00 & 86,75 \\
\hline & $25 \%$ & overlap & 0,83 & 1,44 & 1,64 & 2,24 & 1,54 \\
\hline है & & gaps & 0,47 & 8,35 & 1,41 & 1,67 & 2,98 \\
\hline ON & & displacement & $-30,00$ & $-34,00$ & $-38,00$ & $-36,00$ & 34,50 \\
\hline Е & $50 \%$ & overlap & 1,74 & 1,40 & 2,20 & 2,09 & 1,86 \\
\hline อั & & gaps & 2,93 & 4,27 & 1,76 & 1,48 & 2,61 \\
\hline & & displacement & 27,00 & $-9,70$ & 2,97 & 5,10 & 11,19 \\
\hline & $100 \%$ & overlap & 1,58 & 1,43 & 2,26 & 2,63 & 1,98 \\
\hline & & gaps & 2,55 & 1,88 & 1,76 & 1,46 & 1,91 \\
\hline & & displacement & 53,00 & 80,00 & 22,50 & 2,52 & 39,51 \\
\hline & Average & overlap & 1,36 & 1,32 & 2,39 & 2,03 & \\
\hline & by equal & gaps & 1,60 & 5,23 & 1,62 & 1,46 & \\
\hline & rotation & displacement & 44,50 & 42,43 & 60,87 & 24,16 & \\
\hline
\end{tabular}

clusion leads to review the degree of constriction of the regional strike-slip models focused on rotational data. In these structural models the shortening data will remain as a very important feature in the moment of making a structural model.

We can also note that in the numerical model with full data, there are small blocks that suffer large overlap (e.g., blocks 35, 36, Fig. 7) and rotation (e.g., block 9, Fig. 7) in proportion to their size. It is possible that in the case of blocks 35 and 36, shortening was overestimated, which would explain the significant overlap. In the case of block 9, rotation may also be overestimated, since it does not fit well with the contiguous blocks (Fig. 7). The imprecision of the rotation and shortening data would be caused by blind structures and vertical deformation that are not considered in the characterization of the blocks of the studied sandbox experiment. These surely have associated strain vectors that cannot be displayed fully in a two-dimensional plan view, on which the definition of individual blocks is based. Therefore, the numerical method would not receive all the input data which would allow a perfect fit restoration. Besides, the numerical model showed that the first-order structural system is similar to that obtained in the sandbox. Considering that this structural system is locally transpressional, with a combination of strike-slip and reverse faults, it is important to recognize the nature of every fault plane. It is important also to emphasize that the basement structures are not necessarily reflected by the same geometry at the surface. This idea is shown by Yagupsky et al. (2008), where the surface structures have a strike more consistent with the direction of the deformation front than with the discontinuities of the basement. Therefore, in the construction of a two-dimensional numerical model, depth information is required in order to obtain a more realistic model.

The data obtained is dependant on the geometry of individual blocks, because a larger number of blocks will represent a more realistic distribution of stress and a more precise model of a strike-slip system and associated restraining zones.

\section{Discussion}

In the analogue experiments carried out we examined the influence of oblique structures in the basement in the superficial deformation of strike-slip systems. To this end we created setups to generate all the possible combinations of strike-slip systems, where oblique basement structures were represented by stepover at the base and which were overlain by a sedimentary cover. Our idea was to produce pure and transpressional-transtensional tectonics using offset dextral strike-slip systems and generating antiformal pop-up structures and pull-apart basins. 
The analysis showed interesting progressions for the pop-up structures in the northern sector of the experiments, as they were the best represented.

The main conclusions of the experiments are: a. that a greater angle $\left(90^{\circ}\right.$ maximum) between the basal oblique structures (or stepovers) and the main strike-slip system produces a greater internal rotation of blocks in the pop-up structures; $\mathbf{b}$. that a greater angle $\left(90^{\circ}\right.$ maximum) between the principal stress vector (or convergence angle) and the basal oblique structures (or stepovers) causes greater global uplift of the pop-up and a lower rotation of internal blocks; $\mathbf{c}$. the resulting geometry between reverse faults and synthetic and antithetic strike-slip faults is controlled by the relationship between the principal stress vector (or convergence angle) and the basal oblique structures (or stepovers) of the global strike-slip system.

A real case where these results can be applied is the Main Andes Cordillera of central Chile, between $32.5^{\circ}$ and $34^{\circ} \mathrm{S}$ (Fig. 9). This area is characterized by three main sets of reverse faults related to a Miocene tectonic inversion: two to the west and verging W, the Infiernillo Fault System (IFS) and the San Ramón-Pocuro Fault System (SRFS) and one to the east of E vergence, the El Diablo-El Fierro Fault System (EDFS) (Fig. 9) (e.g., Charrier et al., 2002; Fock et al., 2006). The western systems have an approximately N-S direction and the eastern system is curved, changing from north to south to NW, N-S and NE strikes (Fig. 9). In the northern part of this area, between the Los Andes and Santiago sectors, a dextral strike-slip system has been recognized (sector A in Fig. 9), which is NE oriented and placed between the IFS and the EDFS (Rivera and Yáñez, 2009). In the southern part of the zone, in the northeastern area of Rancagua, a sinistral NW oriented strike-slip system has been recognized within the IFS and EDFS (Sector B in Fig. 9) (Rivera and Yáñez, 2009). If we analyze these structural systems using our analogue modelling results, it is clear that the system of northern dextral direction would be associated with the principal stress direction that generated or activated major thrust faults, and they would correspond to synthetic Riedel structures. If we consider that the southern sinistral strike-slip fault system is contemporary with the northern dextral strike-slip fault system and the reverse faults, it is likely that these faults are antithetic (R'). This would be consistent with existing tectonic data of this area, which indicate that the main stress vector generated most of the reverse faults and, therefore, is almost perpendicular to the main N-S structure system. Moreover, the NW system in the south would be favored by the presence of pre-existing faults in the Paleozoic basement, possibly with the same orientations which are recognized in the Coastal Cordillera (Gana et al., 1996) and in geophysical anomalies in the region (Yáñez et al., 1998; Arriagada et al., 2009; Arriagada, 2011). In the Principal Cordillera (PC, Fig. 9) these deep faults would be represented on the surface by the deformation of the Cenozoic cover between the IFS and the EDFS (Rivera and Cembrano, 2000). The application and analysis have two connotations; one indicating that the analyzed system has major reverse faults that should have an important dextral strike-slip component of motion, as also evidenced by its heterogeneous geometry. This strike-slip component has been shown for example in the study of Campbell (2005), who indicates a dextral movement along the SRFS (Fig. 9). The other significant implication is the proposal of a simple deformational model in an area of considerable debate (e.g., Charrier et al., 2002; Fock et al., 2006; Rivera and Yáñez, 2009), in which there are reverse faults and strike-slip faults that are perfectly compatible.

Regarding the numerical restoration of the sandbox experiment with $30^{\circ}$ convergence angle and $30^{\circ}$ stepover, we can reach one main conclusion. The sensitivity analysis (section 3.2 ) shows that the numerical models are very sensitive to the shortening data, since these data control how the blocks will move and thus have a strong influence on gaps and overlaps between blocks. But, it does not reduce the importance of the rotational data, which have a great control on the overlap percentage in the numerical models.

In this context, the type of studied lithology will affect the robustness of the numerical model. If this is used in areas entirely composed of granite or other rigid rocks, then discrete block model will correspond to the reality of the weak fracture zones as is shown by Astudillo et al. (2008) and Ramírez (2007). However, for less rigid rocks such as limestones in stratified sequences, the shear block models will be more accurate to the extent that they represent internal deformations. Thus, depending on the rheology of the rock, and in order to obtain a better fit of the numerical model with a real case scenario, we will either assign more relevance to internal or external block deformation (Bourgeois et al., 1997). 


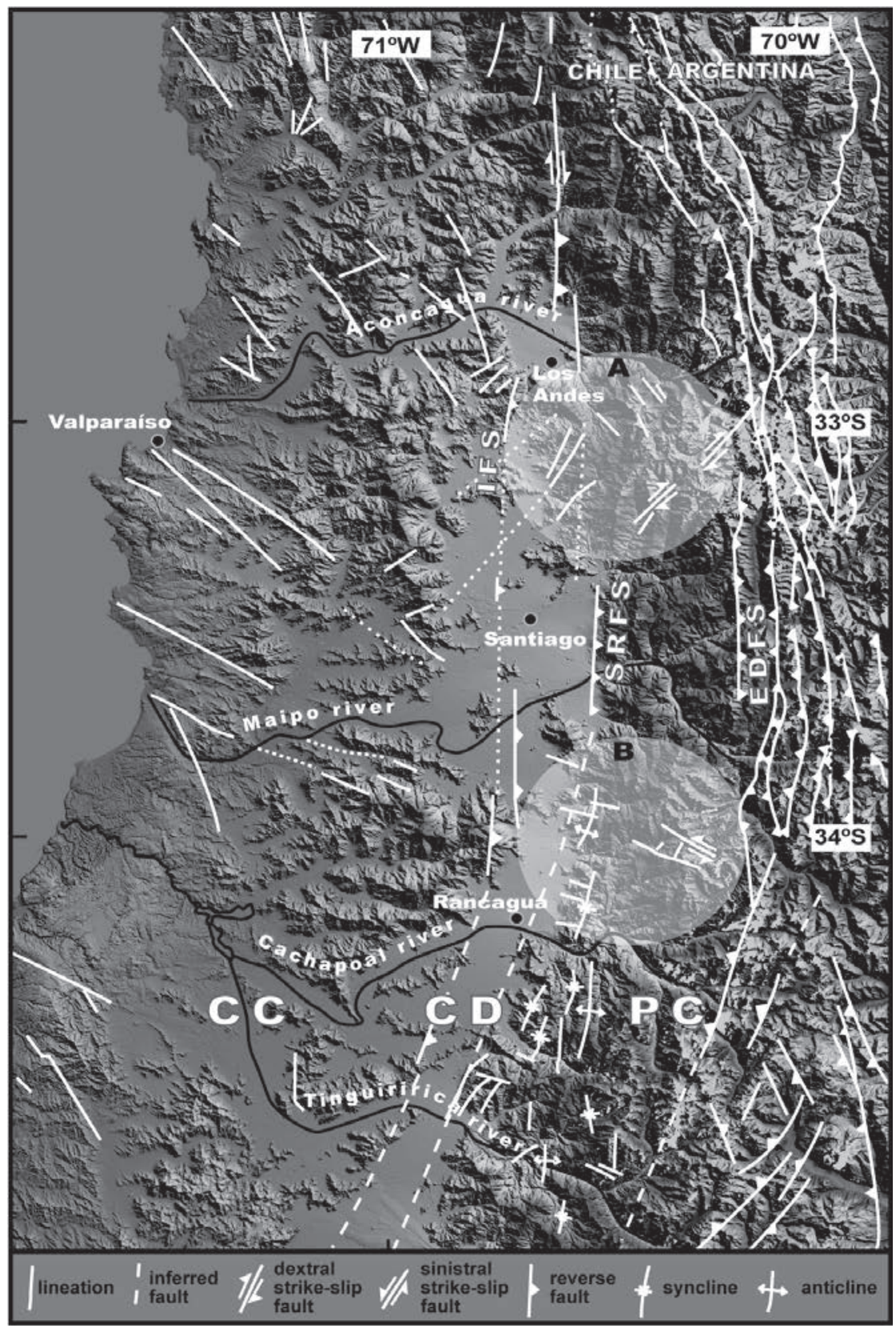

FIG. 9. Schematic structural systems in Central Chile at $32^{\circ}-35^{\circ} \mathrm{S}$. Sectors A and B are indicated to compare with analogue models (see text for more details) (based on Rivano et al., 1993; Cegarra, 1994; Cristallini, 1996; Cristallini et al., 1996; Ramos et al., 1996; Sernageomin, 2002; Giambiagi et al., 2003a, b; Fock, 2005; Farías et al., 2008; Jara et al., 2009). Symbology: CC: Coastal Cordillera; CD: Central Depression; PC: Principal Cordillera; IFS: Infiernillo Fault System; SRFS: San Ramón-Pocuro Fault System; EDFS: El Diablo-El Fierro Fault System. White lines indicate structures explained in the bottom legend.

For future studies, it would be interesting to make digital restoration of the deformation in the Central Chile area discussed above. Here it will be crucial to have detailed maps and structural sections that include the maximum amount of shortening and rotation data to establish an appropriate model restoration, as has been shown in this study. 


\section{Conclusions}

The study of analogue and numeric models yield interesting results regarding the geometry of pure and transpressional-transtensional strike-slip systems, as well as clarifying the restoration required to analyze real cases. One of the most interesting results regarding oblique structures at the base is that if they have greater angles with respect to the main strike-slip system, more rotations will occur in restraining areas with antiformal pop-up structures. However, where they form a greater angle to the main stress system, uplift will be greater and less rotation will occur. This result is directly related to the developed structural style, the case of major rotations being associated with the development of several strike-slip faults, while further uplift is associated with greater shortening absorbed by reverse faults. This result can be used in the study of real cases, in which either basal structures (stepovers) or the main stress vectors (convergence angles) are unknown.

Moreover, the restoration for a pop-up structure gave comparable results to the undistorted state shown by the initial state of the analogue experiment. The analysis of numerical models shows that the restoration is very sensitive to the shortening data as well as rotational data. This result should be considered in restoration models of real cases in which the shortening data should be given importance.

\section{Acknowledgments}

We acknowledge funding from Proyecto Anillo ACT-18 (R. Charrier) and Proyecto Fondecyt 1090165 (L. Pinto). We also thank support from the Departamento de Geología, Universidad de Chile. Careful reviews by J. Le Roux (Universidad de Chile), F. Barra (Universidad de Chile), M. Ghiglione (CONICET) and E. Rojas Vera (CONICET) helped greatly to improve the manuscript.

\section{References}

Amilibia, A.; Sàbat, F.; McClay, K.R.; Muñoz, J.A.; Roca, E.; Chong, G. 2008. The role of inherited tectono-sedimentary architecture in the development of the central Andean mountain belt: Insights from the Cordillera de Domeyko. Journal of Structural Geology 30: 1520-1539.

Arriagada, C. 2011. Rotaciones tectónicas en Chile Central: Los oroclinos del Maipo y Vallenar. In Congreso Geológico Argentino, No. 18, Actas S12: 695-696. Neuquén.
Arriagada, C.; Roperch, P.; Mpodozis, C.; Cobbold, P.R. 2008. Paleogene building of the Bolivian Orocline: Tectonic restoration of the central Andes in 2-D map view. Tectonics 27: 14 p. doi:10.1029/2008TC002269.

Arriagada, C.; Mpodozis, C.; Yáñez, G.; Charrier, R.; Farías, M.; Roperch, P. 2009. Rotaciones tectónicas en Chile central: El oroclino de Vallenar y el 'megakink' del Maipo. In Congreso Geológico Chileno, No. 12, Actas S9-09: 4 p. Santiago.

Astudillo, N.; Roperch, P.; Townley, B.; Arriagada, C.; Maksaev, V. 2008. Importance of small-block rotations in damage zones along transcurrent faults. Evidence from the Chuquicamata open pit, Northern Chile. Tectonophysics 450: 1-20.

Bourgeois, O.; Cobbold, P. R.; Rouby, D.; Thomas, J. 1997. Least squares restoration of Tertiary thrust sheets in map view, Tajik depression, central Asia. Journal of Geophysical Research 102: 553-573.

Campbell, D. 2005. Termocronología del sector comprendido entre los ríos Rocín y Aconcagua: Implicancias en la evolución meso-cenozoica de la zona. Memoria de Título (Inédito), Departamento de Geología, Universidad de Chile: 113 p.

Cegarra, M.I. 1994. Análisis de la faja plegada y corrida al norte del río Cuevas, Alta Cordillera de Mendoza. Ph.D. Thesis (Unpublished), Universidad de Buenos Aires: 297 p.

Cembrano, J.; Beck, M.E. Jr.; Burmester, R.F.; Rojas, C.; García, A.; Hervé, F. 1992. Paleomagnetism of Lower Cretaceous Rocks from east of the Liquiñe-Ofqui fault zone, southern Chile: evidence of small in-situ clock-wise rotations. Earth and Planetary Science Letters 113: 539-551.

Cembrano, J.; Hervé, F.; Lavenu, A. 1996. The Liquiñe Ofqui Fault Zone: a long-lived intra-arc fault system in southern Chile. Tectonophysics 259: 55-66.

Cembrano, J.; Schermer, E.; Lavenu, A.; Sanhueza, A. 2000. Contrasting nature of deformation along an intra-arc shear zone, the Liquiñe-Ofqui Fault Zone, southern Chilean Andes. Tectonophysics 319: 129-142.

Cembrano, J.; González, G.; Arancibia, G.; Ahumada, I.; Olivares, V.; Herrera, V. 2005. Fault zone development and strain partitioning in an extensional strike-slip duplex: A case study from the Mesozoic Atacama fault system, northern Chile. Tectonophysics 400: 105-125.

Charrier, R.; Baeza, O.; Elgueta, S.; Flynn, J.J.; Gans, P.; Kay, S.M.; Muñoz, N.; Wyss, A.R.; Zurita, E. 2002. Evidence for Cenozoic extensional basin development and tectonic inversion south of the flat-slab segment,

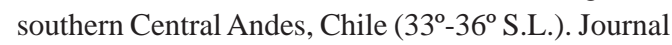
of South American Earth 15: 117-139. 
Charrier, R.; Farías, M.; Maksaev, V. 2009. Evolución tectónica, paleogeográfica y metalogénica durante el Cenozoico en los Andes de Chile norte y central e implicaciones para las regiones adyacentes de Bolivia y Argentina. Revista de la Asociación Geológica Argentina 65: 5-35.

Christie-Blick, N.; Biddle, K.T. 1985. Deformation and basin formation along strike-slip faults. In Strike-slip deformation, basin formation, and sedimentation (Biddle, K.T.; Christie-Blick, N.; editors). Society of Economic Paleontologists and Mineralogists (SEPM), Special Publication 37, 1-34.

Cristallini, E.O. 1996. Plegamiento por despegue en la Alta Cordillera de San Juan a los $32^{\circ} \mathrm{S}$, Argentina. In Congreso Geológico Argentino, No. 13 y Congreso de Exploración de Hidrocarburos, No. 3, Actas 2: 325-336. Buenos Aires.

Cristallini, E.O.; Álvarez, P.; Ramos, V.A.; Pérez, D.J. 1996. Carta Geológica, Región de La Ramada. In Geología de la región del Aconcagua, provincias de San Juan y Mendoza (Ramos, V.A.; editor). Subsecretaría de Minería de la Nación, Dirección Nacional del Servicio Geológico Argentino, Anales 24 (13): 349-385. Buenos Aires.

Farías, M.; Charrier, R.; Carretier, S.; Martinod, J.; Fock, A.; Campbell, D.; Cáceres, J.; Comte, D. 2008. Late Miocene high and rapid surface uplift and its erosional

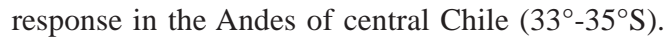
Tectonics 27, TC1005. doi:10.1029/2006TC002046.

Fock, A. 2005. Cronología y tectónica de la exhumación en el Neógeno de los Andes de Chile central entre los $33^{\circ} \mathrm{y}$ los $34^{\circ} \mathrm{S}$. M.Sc. Thesis (Unpublished), Departamento de Geología, Universidad de Chile: 179 p.

Fock, A.; Charrier, R.; Farías, M.; Muñoz, M. 2006. Fallas de vergencia oeste en la Cordillera Principal de Chile Central: Inversión de la cuenca de Abanico $\left(33^{\circ}-34^{\circ} \mathrm{S}\right)$. Revista de la Asociación Geológica Argentina, Special Publication 6: 48-55.

Gana, P.; Wall, R.; Gutiérrez, A. 1996. Mapa geológico del área Valparaíso-Curacaví, regiones de Valparaíso y Metropolitana. Servicio Nacional de Geología y Minería, Mapas Geológicos, No. 1, 1 mapa escala 1:100.000, 1 anexo.

Giambiagi, L.B.; Ramos, V.A.; Godoy, E.; Álvarez, P.P.; Orts, S. 2003a. Cenozoic deformation and tectonic style of the Andes, between $33^{\circ}$ and $34^{\circ}$ South Latitude. Tectonics 22 (4), 1041. doi:10.1029/2001TC001354.

Giambiagi, L.B.; Álvarez, P.P.; Godoy, E.; Ramos, V.A. 2003b. The control of pre-existing extensional structures in the evolution of the southern sector of the Aconcagua fold and thrust belt. Tectonophysics 369: 1-19.

Grocott, J.; Taylor, G.K. 2002. Magmatic arc fault systems, deformation partitioning and emplacement of granitic complexes in the Coastal Cordillera, north Chilean Andes (2530'S to $27^{\circ} 00^{\prime} \mathrm{S}$ ). Journal of the Geological Society of London 159: 425-442.

Horsfield, W.T. 1977. An experimental approach to basement controlled faulting. Geologie en Mijnbouw 56: 363-370.

Jara, P.; Piquer, J.; Pinto, L.; Arriagada C.; Charrier, R.; Rivera, O. 2009. Perfiles estructurales de la Cordillera Principal de Chile Central: resultados preliminares. In Congreso Geológico Chileno, No. 12, S9-038: 4 p. Santiago.

Kuhn, D.; Reuther, C.-D. 1999. Strike-slip faulting and nested block rotations: structural evidence from the Cordillera de Domeyko, northern Chile. Tectonophysics 313: 383-398.

Lallemand, S.; Malavieille, J.; Calassou, S. 1992. Effects of oceanic ridge subduction on accretionary wedges. Tectonics 11: 1301-1313.

Malavieille, J.; Calassou, S.; Larroque, C. 1993. Modelisation experimentale des relations tectonique sedimentation entre bassin avant-arc et prisme d'accretion. Comptes Rendus de l'Académie des Sciences 316: 1131-1137.

Martínez, F.; Arriagada, C.; Mpodozis, C.; Peña, M.; Salazar, E. 2009. Sección estructural balanceada entre Iglesia Colorada y Tranque Lautaro (Región de Copiapó): inversión tectónica de cuencas extensionales del Triásico y Jurásico (Cuenca Lautaro). In Congreso Geológico Chileno, No. 12, S9-44. Santiago.

McClay, K.R. 1990. Deformation mechanics in analogue models of extensional fault systems. In Deformation Mechanisms, Rheology and Tectonics (Rutter, E.H.; Knipe, R.J.; editors). Geological Society, Special Publication 54: 445:454.

McClay, K.; Bonora, M. 2001. Analog models of restraining stepovers in strike-slip fault systems. American Association of Petroleum Geologists, Bulletin 85: 233-260.

McClay, K.; Dooley, T. 1995. Analog models of pull-aparts. Geology 23: 711-714.

Mandl, G. 1988. Mechanics of tectonic faulting. Netherlands. Elsevier: 407 p.

Naylor, M.A.; Mandl, G.; Sijpesteijn, C.H.K. 1986. Fault geometries in basement-induced wrench faulting under different initial stress states. Journal of Structural Geology 8: 737-752. 
Pardo-Casas, F.; Molnar, P. 1987. Relative motion of the Nazca (Farallon) and South American plates since Late Cretaceous time. Tectonics 6: 233-248.

Peña, M.; Arriagada, C.; Mpodozis, C.; Martínez, F.; Salazar, E. 2009. Rotaciones tectónicas sobreimpuestas en la zona Centro-Sur de la Región de Atacama: Primeros resultados de un estudio estructural y paleomagnético. In Congreso Geológico Chileno, No. 12, S9-61. Santiago.

Ramírez, L.E. 2007. Metalogénesis, petrogénesis y tectónica del distrito minero de Mantos Blancos, Cordillera de la Costa, norte de Chile. Thesis (Unpublished), Universidad de Chile: 178 p.

Ramos, V.A.; Cegarra, M.I.; Pérez, D.J. 1996. Carta Geológica, Región del Aconcagua. In Geología de la región del Aconcagua, provincias de San Juan y Mendoza (Ramos, V.A.; editor). Subsecretaría de Minería de la Nación, Dirección Nacional del Servicio Geológico, Buenos Aires, Anales 24 (11).

Reutter, K.; Scheuber, E.; Chong, G. 1996. The Precordilleran fault system of Chuquicamata, Northern Chile: evidence for reversals along arc-parallel strike-slip faults. Tectonophysics 259: 213-228.

Richard, P.D.; Ballard, J.F.; Colletta, B.; Cobbold, P.R. 1989. Fault initiation and development above a basement strike-slip fault: analogue modelling and tomography. Comptes Rendus de l'Académie des Sciences 309: 2111-2118.

Richard, P.D.; Naylor, M.A.; Koopman, A. 1995. Experimental models of strike-slip tectonics. Petroleum Geoscience 1: 71-80.

Rivano, S.; Sepúlveda, P.; Boric, R.; Espiñeira, D. 1993. Hojas Quillota y Portillo, V Región Servicio Nacional de Geología y Minería, Carta Geológica de Chile 73, 1 mapa 1:250.000 (acompaña Informe Inédito 7644). Santiago.

Rivera, O.; Cembrano, J. 2000. Modelo de formación de cuencas volcano-tectónicas en zonas de transferencia oblicuas a la cadena andina: el caso de las cuencas oligo-miocénicas de Chile central y su relación con estructuras NWW-NW (3300'-34³0'S). In Congreso Geológico Chileno, No. 9, Actas 2: 631-636. PuertoVaras.

Rivera, O.; Yáñez, G. 2009. Naturaleza y rol de estructuras translitosféricas en la evolución del arco volcánico oligo-mioceno de Chile Central entre los $32^{\circ}$ y $34^{\circ}$ S. In Congreso Geológico Chileno, No. 12, Sesión 9-092: 4 p. Santiago.

Rouby, D.; Cobbold, P.R.; Szatmari, P.; Demercian, D.; Coelho, D.; Rici, J.A. 1993. Least-squares palinspastic restoration of regions of normal faulting application to the Campos Basin (Brazil). Tectonophysics 221: 439-452. doi:10.1016/0040-1951(93)90172-G.

Rouby, D.; Fossen, H.; Cobbold, P. 1996. Extension, displacement, and block rotation in the larger Gullfaks area, northern North Sea: determined from map view restoration. American Association of Petroleum Geologists, Bulletin 80 (6): 875-890.

Scheuber, E.; Andriessen, P.A.M. 1990. The kinematic and geodynamic significance of the Atacama Fault Zone, northern Chile. Journal of Structural Geology 12: 243-257.

Scheuber, E.; Giese, P. 1999. Architecture of the Central Andes-a compilation of geoscientific data along a transect at $21^{\circ} \mathrm{S}$. Journal of South American Earth Sciences 12: 103-107.

Scheuber, E.; Bogdanic, T.; Jensen, A.; Reutter, K.J. 1994. Tectonic development of the Nonh Chilean Andes in relation to plate convergence and magmatism since the Jurassic. In Reutter, K.J.; Scheuber, E.; Wigger, P.; editors). Tectonics of the Southern Central Andes, Springer Verlag: 121-139.

Schreurs, G. 1994. Experiments on strike-slip faulting and block rotation. Geology 22: 567-570.

Servicio Nacional de Geología y Minería (Sernageomin) 2002. Mapa Geológico de Chile. Servicio Nacional de Geología y Minería, Carta Geológica de Chile 75, 1 mapa en 3 hojas, escala 1:1.000.000.

Sylvester, A.G.; Smith, R.R. 1987. Structure section in Painted Canyon, Mecca Hills, southern California. In Centennial field guide volume 1. Cordilleran Section (Hill, M.L.; editor). Geological Society of America: 103-108.

Taylor, G.K.; Grocott, J.; Pope, A.; Randall, D.E. 1998. Mesozoic fault systems, deformation and fault block rotation in the Andean forearc: a crustal scale strikeslip duplex in the Coastal Cordillera of northern Chile. Tectonophysics: 299: 93-109.

Taylor, G.K.; Grocott, J.; Dashwood, B.; Gipson, M.; Arevalo, C. 2007. Implications for crustal rotations and tectonic evolution in the central Andes fore arc: New paleomagnetic results from the Copiapó region of northern Chile, $26^{\circ}-28^{\circ} \mathrm{S}$. Journal of Geophysical Research 112. doi:10.1029/2005JB003950.

Tomlinson, A.; Blanco, N. 1997. Structural evolution and displacement history of the West Fault System, Precordillera, Chile: part 1, Synmineral history. In Congreso Geológico Chileno, No. 8, Actas 3: 18731887. Antofagasta.

Vendeville, B. 1991. Mechanisms generating normal fault curvature: a review illustrated by physical models. In The geometry of normal faults (Roberts, A.M.; Yielding, 
G.; Freeman, B.; editors). Geological Society Special Publication 56: 241-250.

Withjack, M.O.; Olson, J.; Peterson, E. 1990. Experimental models of extensional forced folds. American Association of Petroleum Geologists, Bulletin 74: 1038-1045.

Wu, J.E.; McClay, K.; Whitehouse, P.; Dooley, T. 2009. 4D analogue modelling of transtensional pull-apart basins. Marine and Petroleum Geology 26 (8): 1608-1623.

Yagupsky, D.; Cristallini, E.; Fantín, J.; Zamora, G.; Bottesi, G.; Varadé, R. 2008. Oblique half-graben inversion of the Mesozoic Neuquén Rift in the Malargüe Fold and Thrust Belt, Mendoza, Argentina: New insights from analogue models. Journal of Structural Geology 30: 839-853.

Yáñez G.; Mpodozis, C.; Tomlinson, A. 1994. Eocene dextral oblique convergence and sinistral shear along the Domeyko fault system: a thin viscous sheet approach with asthenospheric drag at the base of the crust. In Congreso Geológico Chileno, No. 7. Concepción.

Yáñez, G.; Gana, P.; Fernández, R. 1998. Origen y significado geológico de la Anomalía Melipilla, Chile central. Revista Geológica de Chile 25 (2): 175-198.

Manuscript received: April 25, 2011; revised/accepted: October 24, 2011; available online: November 8, 2011. 